Louisiana State University

LSU Digital Commons

$9-1-2016$

\title{
Do ploidy level and nuclear genome size and latitude of origin modify the expression of Phragmites australis traits and interactions with herbivores?
}

\author{
Laura A. Meyerson \\ University of Rhode Island \\ James T. Cronin \\ Louisiana State University \\ Ganesh P. Bhattarai \\ Louisiana State University \\ Hans Brix \\ Aarhus Universitet \\ Carla Lambertini \\ Aarhus Universitet
}

See next page for additional authors

Follow this and additional works at: https://digitalcommons.Isu.edu/biosci_pubs

\section{Recommended Citation}

Meyerson, L., Cronin, J., Bhattarai, G., Brix, H., Lambertini, C., Lučanová, M., Rinehart, S., Suda, J., \& Pyšek, P. (2016). Do ploidy level and nuclear genome size and latitude of origin modify the expression of Phragmites australis traits and interactions with herbivores?. Biological Invasions, 18 (9), 2531-2549. https://doi.org/10.1007/s10530-016-1200-8 


\section{Authors}

Laura A. Meyerson, James T. Cronin, Ganesh P. Bhattarai, Hans Brix, Carla Lambertini, Magdalena Lučanová, Shelby Rinehart, Jan Suda, and Petr Pyšek 


\title{
Do ploidy level and nuclear genome size and latitude of origin modify the expression of Phragmites australis traits and interactions with herbivores?
}

\author{
Laura A. Meyerson $(\mathbb{D} \cdot$ James T. Cronin - Ganesh P. Bhattarai • \\ Hans Brix • Carla Lambertini • Magdalena Lučanová • \\ Shelby Rinehart $\cdot$ Jan Suda $\cdot$ Petr Pyšek
}

Received: 28 December 2015/Accepted: 19 June 2016/Published online: 29 June 2016

(C) Springer International Publishing Switzerland 2016

\begin{abstract}
We studied the relationship between genome size and ploidy level variation and plant traits for the reed grass Phragmites australis. Using a common garden approach on a global collection of populations in Aarhus, Denmark, we investigated the influence of monoploid genome size and ploidy level on the expression of $P$. australis growth, nutrition and herbivore-defense traits and whether monoploid genome size and ploidy level play different roles in plant trait expression. We found that both monoploid genome size and latitude of origin contributed to
\end{abstract}

Guest editors: Laura A. Meyerson and Kristin Saltonstall/ Phragmites invasion.

L. A. Meyerson $(\bowtie) \cdot$ S. Rinehart

The University of Rhode Island, Kingston, RI 02881 ,

USA

e-mail: lameyerson@uri.edu

J. T. Cronin - G. P. Bhattarai

Louisiana State University, Baton Rouge, LA, USA

G. P. Bhattarai

Indian River Research and Education Center, University of Florida, Fort Pierce, FL, USA

H. Brix · C. Lambertini

Department of Bioscience, Plant Biology, Aarhus

University, Ole Worms Alle 1, 8000 Aarhus C, Denmark

M. Lučanová · J. Suda · P. Pyšek

Institute of Botany, The Czech Academy of Sciences,

Zámek 1, 25243 Průhonice, Czech Republic variation in traits that we studied for $P$. australis, with latitude of origin being generally a better predictor of trait values and that ploidy level and its interaction with monoploid genome size and latitude of origin also contributed to trait variation. We also found that for four traits, tetraploids and octoploids had different relationships with the monoploid genome size. While for tetraploids stem height and leaf water content showed a positive relationship with monoploid genome size, octoploids had a negative relationship with monoploid genome size for stem height and no relationship for leaf water content. As genome size within octoploids increased, the number of aphids colonizing leaves decreased, whereas for tetraploids

\footnotetext{
S. Rinehart

Department of Biology, San Diego State University, San Diego, CA, USA

S. Rinehart

Department of Evolution and Ecology, University of California, Davis, Davis, CA, USA

M. Lučanová · J. Suda

Department of Botany, Faculty of Science, Charles University in Prague, Benátská 2, 12800 Prague, Czech Republic

P. Pyšek

Department of Ecology, Faculty of Science, Charles University in Prague, Viničná 7, 12844 Prague, Czech Republic
} 
there was a quadratic, though non-significant, relationship. Generally we found that tetraploids were taller, chemically better defended, had a greater number of stems, higher leaf water content, and supported more aphids than octoploids. Our results suggest trade-offs among plant traits mediated by genome size and ploidy with respect to fitness and defense. We also found that the latitude of plant origin is a significant determinant of trait expression suggesting local adaptation. Global climate change may favor some genome size and ploidy variants that can tolerate stressful environments due to greater phenotypic plasticity and to fitness traits that vary with cytotype which may lead to changes in population genome sizes and/or ploidy structure, particularly at species' range limits.

Keywords Cytotype - Global climate change · Latitude of origin - Nuclear genome size · Plant defense $\cdot$ Plant invasion · Polyploidy

\section{Introduction}

Identifying traits that facilitate the success of invasive species and predicting outcomes of the interactions of such traits with the environment continues to be a priority for invasion ecologists (Küster et al. 2008; Pyšek et al. 2009, 2015). Over the last two decades it has become clear that no single trait can account for the invasion success of a species (Thébault et al. 2011) and invasion success can also vary over biogeographic space further complicating the identification of key invasive traits (Cronin et al. 2015).

Studies searching for determinants of invasiveness rarely consider underlying genetic factors such as genetic polymorphism, heterozygosity, and karyological factors, such as nuclear genome size, number of somatic chromosomes and ploidy level—all of which may differentially modify plant traits and interact with each other and environmental factors (e.g., climate) to affect trait expression (te Beest et al. 2011; Suda et al. 2015). Understanding how karyological variation (genome size and ploidy) influences plant traits across a range of environments is of particular interest for researchers seeking to improve predictive capacities in species invasions and range expansions (Suda et al. 2015). Moreover, studies have increasingly identified the role of intraspecific variation in contributing to the ecological breadth of a species and its ability to adapt to changing environments (Albert et al. 2010; Sides et al. 2014). Greater intraspecific functional variability is predicted to allow plant populations to adjust to a wider range of competitive and abiotic conditions thereby conferring a broader niche (Sides et al. 2014). Some evidence indicates that within-species genetic variation mirrors interspecific diversity (e.g. Hughes and Stachowicz 2004; Stachowicz et al. 2007; Cardinale et al. 2012) and that intraspecific variation, including karyological diversity, may drive community structure and ecosystem processes (Levin 2002; Reusch and Hughes 2006; Johnson et al. 2009; Crawford and Rudgers 2013) via plant functional traits (Lavorel et al. 2007; Hull-Sanders et al. 2009). Intraspecific functional variation may be important at small and intermediate scales due to environmental filtering and high interspecific variability at the global scale (Albert et al. 2010), and because adaptation to change plays out at the population and subpopulation scales (e.g., microevolutionary scale; Balao et al. 2011).

Both genome size and ploidy level have previously been implicated in invasion success (e.g. Kubešová et al. 2010; te Beest et al. 2011; Suda et al. 2015) but rarely considered simultaneously (but see Balao et al. 2011), even though including both in explanatory models may greatly increase their power to predict invasiveness (Pandit et al. 2014). For example, polyploidy can facilitate invasion success by "pre-adapting" species to conditions in the introduced range relative to diploids, and the associated higher genetic diversity in polyploids may enhance invasiveness (Henery et al. 2010; te Beest et al. 2011) whereas smaller holoploid (C-value) and monoploid (CX-value) genome sizes (sensu Greilhuber et al. 2005) often contribute to faster growth rates (e.g. Lavergne et al. 2010; Fridley and Craddock 2015). Holoploid genome size is the amount of DNA in the whole chromosome complement of the nucleus with a chromosome number $n$, irrespective of ploidy number whereas monoploid genome size is the amount of DNA in one chromosome set of an organism (Suda et al. 2015).

Currently, little is also known about whether tradeoffs exist between intraspecific cytotypes with respect to plant functional traits (but see Thébault et al. 2011; Hao et al. 2013), including plant defense against herbivores and pathogens, and most work in this direction has examined differences between diploids and higher ploidy levels. Data on enemy impact and 
plant defenses in relation to ploidy level and genome size is sparse (Janz and Thompson 2002; Münzbergová 2006; Halverson et al. 2008; Hull-Sanders et al. 2009; Arvanitis et al. 2010; Hahn and Dornbush 2012) even though herbivores and pathogens play an important role in invasion success (e.g. Keane and Crawley 2002; Mitchell and Power 2003; Fagan et al. 2005; Mitchell et al. 2010). One example involves Cardamine pratensis where octoploids exhibited greater tolerance to herbivory than tetraploids (Boalt et al. 2010). Importantly, a gall-forming midge only attacked the octoploid suggesting that changes in ploidy can lead to host shifts in herbivores (Arvanitis et al. 2010). In other species, different cytotypes can suffer higher or lower levels of attack depending on both the plant and herbivore or pathogen (Halverson et al. 2008; Thompson and Merg 2008; Collins et al. 2013).

To gain greater insight into the roles of genome size and ploidy level variation in an invasive plant, we studied plant traits for the reed grass Phragmites australis - one of the best-studied plant species globally (Hulme et al. 2013; Meyerson et al. 2016). This topic is of particular interest because of the important habitat, including ecosystem services, reed grass provides across its native range in Europe and Asia, and its status as a highly invasive species in North America (Chambers et al. 1999; Kiviat 2013; Packer et al. 2016). $P$. australis is an ideal model species to investigate the interactions of genome size, ploidy level and plant traits because of its global distribution, high genetic and genomic diversity, and habitat breadth, ranging from brackish to freshwater systems, temperate to tropical, coastal to inland to high elevation (Meyerson et al. 2016). Using a common garden approach on a global collection of populations, we investigated (1) the influence of monoploid genome size and ploidy level on the expression of $P$. australis growth, nutrition herbivore-defense traits, and palatability to aphids, (2) and whether monoploid genome size and ploidy level play different roles in plant trait expression.

\section{Methods}

Plant material

We used the living collection of $P$. australis from a common garden at Aarhus University, Denmark $\left(56^{\circ} 81^{\prime} 30^{\prime \prime} \mathrm{N} ; 10^{\circ} 80^{\prime} 70^{\prime \prime} \mathrm{E}\right)$ during the summer of 2012 to examine the relationship between plant traits, genome size and ploidy (see "Appendix"), and herbivory. $P$. australis is a cosmopolitan species within Poaceae and is adapted to wide climatic and latitudinal ranges $\left( \pm 60^{\circ}\right)$, including extreme environments. It exhibits a high genetic diversity (Saltonstall 2002), intra- and interspecific hybridization (Meyerson et al. 2010, 2012; Lambertini et al. 2012) and variation in ploidy (Clevering and Lissner 1999; Keller 2000; Lambertini et al. 2006). The species has globally distributed diverse cytotypes $(4 x-12 x$, based on $x=12$ ) and GS variability up to $22 \%$ within cytotypes (Suda et al. 2015).

One hundred and sixty-six clones were planted in the garden in 2001. A decade passed prior to the start of this study, allowing plenty of time for the plants to acclimate to the Danish climate and for maternal environmental effects to have been virtually eliminated. All pots were maintained under identical watering (daily) and fertilization regimes (monthly) and all rhizomes were divided during spring 2012 and repotted in $60 \mathrm{~L}$ pots using commercial potting soil and sand mixture. Given the large genetic and genomic variation represented for $P$. australis in this common garden, the collection made it possible to address, at the intraspecific level, fundamental relationships among genetics and the environment (i.e. geography and herbivory).

\section{Genome size estimation}

Holoploid genome sizes (i.e., the DNA content of the whole chromosome complement with chromosome number $n$ irrespective of the degree of generative polyploidy; C-value) of analyzed plants were estimated using DNA flow cytometry following the simplified two step protocol using the Otto buffers as detailed in Doležel et al. (2007). Bellis perennis (2C $=3.38$ pg; Schönswetter et al. 2007) was used as an internal reference standard and the nuclei isolated from intact young leaves of actively growing plants were stained by the intercalating fluorochrome propidium iodide. Karyologically confirmed tetraploid $(2 n=4 x=48)$ and octoploid $(2 n=8 x=96)$ Phragmites samples from the living collection of the Institute of Botany, The Czech Academy of Sciences in Průhonice were used as reference points to infer DNA ploidy levels of analyzed samples. Monoploid 
genome sizes (i.e., the DNA content of the monoploid chromosome set, with chromosome number $\mathrm{x}$; $\mathrm{Cx}$ value) were calculated as $2 \mathrm{C}$-value/ploidy level.

\section{Growth, nutritional and defense traits}

We measured 10 plant traits (Table 1) related to growth (stem height and number, the latter measured as the stem number per pot), nutritional quality (\% carbon, \% nitrogen, C:N), herbivore defense (total phenolics, leaf toughness), ambient aphid abundance per stem, and palatability to aphids, all in the same pots. Since water content of leaves can have a positive relationship with the population growth rate of aphids (e.g. Johnson 2009; Bhattarai et al. in review), we estimated this trait as the proportion of water per unit fresh biomass of three newly opened leaves collected from each pot. For nutrient analysis (\% carbon, \% nitrogen, $\mathrm{C}: \mathrm{N}$ ratio), the top three leaves were collected during July 2012 from a single plant per pot. Leaves were oven-dried at $70{ }^{\circ} \mathrm{C}$ and ground to a fine powder. Carbon and nitrogen were analyzed using a CE Instruments Model NC2100 elemental analyzer at Brown University Environmental Chemistry Facilities (http://www.brown.edu/Research/Evchem/ facilities).

Leaf toughness and total phenolics were our measures of plant defense against herbivores. In Poaceae, defenses are likely limited to structural defenses and phenolics. Using a penetrometer (Itin Scale Co., Inc., Brooklyn, NY), toughness was measured for the fully open uppermost leaf from a randomly selected stem (force in $\mathrm{kg}$ to push a $4.8 \mathrm{~mm}$ diameter blunt steel rod through the leaf). Total phenolics (nM/g of dried leaf tissue) were estimated using a microplate modified version of the Folin-Ciocalteu method (Waterman and Mole 1994; Cronin et al. 2015).

Aphid abundance and palatability to aphids

A wide diversity of herbivores are known to feed on $P$. australis (Tewksbury et al. 2002). Within Europe and North America, the mealy plum aphid Hyalopterus pruni (Homoptera: Aphididae) is the most common herbivore in terms of numbers and biomass (Cronin et al. 2015). The mealy plum aphid is a Eurasian species that was introduced to North America more than a century ago (Lozier et al. 2009). These aphids overwinter on their primary hosts, various Prunus species, but switch to grasses like $P$. australis during the spring and summer (Lozier et al. 2009). Mealy plum aphids often achieve densities $>1000$ per $P$. australis stem, and outbreaks can cause the die off of all aboveground vegetation (Cronin et al. 2015). We conducted two experiments investigating herbivory by the mealy plum aphid Hyalopterus pruni that has $P$. australis as its summer host.

\section{Ambient aphid abundance per stem}

Background densities of aphids per source population likely reflect a combination of plant defense, nutritional quality, and positional effects (i.e., location in the garden). Historical effects (e.g., temporal autocorrelation in abundance) are unimportant because the mealy plum aphid overwinters on other hosts and then returns to the garden. To quantify ambient aphid abundance, we first counted stems and the proportion of stems that were infested with aphids. Randomly selecting three aphid-infested stems in each pot, we counted the number of leaves with aphids. One infested leaf per stem was chosen at random and the aphids were counted. Mean aphids per stem were then estimated as the proportion of stems infested per pot $\times$ mean number of infested leaves per infested stem $\times$ mean number of aphids per infested leaf.

\section{Palatability to aphids}

We performed a caging experiment to access palatability of $P$. australis populations to mealy-plum aphid (Hyalopterus pruni, Aphididae). We collected aphids from a single source in a naturally occurring stand of $P$. australis within $10 \mathrm{~km}$ of the common garden to minimize the genetic variation among aphids in the experiment. We caged adult aphids on live $P$. australis leaves to assess the palatability of the garden populations to aphids (see Bhattarai et al. in review for details). Aphid colonies were initiated with two adult aphids caged on the youngest fully open leaf on a randomly selected stem from each pot. Aphids reproduce parthenogenetically and produce a colony in a few days. After 10 days, leaves with aphid colonies were collected, transported on ice to the laboratory, and stored in a freezer at $-20{ }^{\circ} \mathrm{C}$. With a suitable host, aphid colonies can increase in size up to 100 times in 
Table 1 Model selection results based on Akaike Information Criteria corrected for finite sample size (AICc)

\begin{tabular}{|c|c|c|c|c|}
\hline Trait & Model & $\mathrm{AICc}$ & $\triangle \mathrm{AICc}$ & Akaike Wt \\
\hline \multirow[t]{5}{*}{$\%$ Carbon } & $\mathrm{Cx}, \mathrm{L}, \mathrm{L} \times \mathrm{L}, \mathrm{H}$ & 287.4 & 0.0 & 0.13 \\
\hline & $\mathrm{P}, \mathrm{Cx}, \mathrm{P} \times \mathrm{Cx}, \mathrm{L}, \mathrm{L} \times \mathrm{L}, \mathrm{H}$ & 287.8 & 0.4 & 0.11 \\
\hline & $\mathrm{L}, \mathrm{L} \times \mathrm{L}, \mathrm{H}$ & 288.0 & 0.6 & 0.10 \\
\hline & $\mathrm{Cx}, \mathrm{L}, \mathrm{Cx} \times \mathrm{L}, \mathrm{L} \times \mathrm{L}, \mathrm{H}$ & 289.1 & 1.7 & 0.06 \\
\hline & $\mathrm{P}, \mathrm{Cx}, \mathrm{L}, \mathrm{L} \times \mathrm{L}, \mathrm{H}$ & 289.2 & 1.8 & 0.05 \\
\hline \multirow[t]{6}{*}{$\%$ Nitrogen } & $\mathrm{Cx}, \mathrm{L}$ & 105.2 & 0.0 & 0.20 \\
\hline & $\mathrm{Cx}, \mathrm{L}, \mathrm{H}$ & 105.6 & 0.5 & 0.16 \\
\hline & $\mathrm{Cx}, \mathrm{L}, \mathrm{Cx} \times \mathrm{L}$ & 106.5 & 1.3 & 0.10 \\
\hline & $\mathrm{P}, \mathrm{Cx}, \mathrm{L}, \mathrm{H}$ & 107.0 & 1.8 & 0.08 \\
\hline & $\mathrm{Cx}, \mathrm{L}, \mathrm{Cx} \times \mathrm{L}, \mathrm{H}$ & 107.1 & 1.9 & 0.08 \\
\hline & $\mathrm{P}, \mathrm{Cx}, \mathrm{L}$ & 107.2 & 2.0 & 0.07 \\
\hline \multirow[t]{3}{*}{$\mathrm{C}: \mathrm{N}$ ratio } & $\mathrm{Cx}, \mathrm{L}, \mathrm{H}$ & 569.8 & 0.0 & 0.35 \\
\hline & $\mathrm{P}, \mathrm{Cx}, \mathrm{L}, \mathrm{H}$ & 571.2 & 1.4 & 0.18 \\
\hline & $\mathrm{Cx}, \mathrm{L}, \mathrm{Cx} \times \mathrm{L}, \mathrm{H}$ & 571.7 & 1.9 & 0.14 \\
\hline \multirow[t]{4}{*}{ Total phenolics } & $\mathrm{P}, \mathrm{H}$ & 75.6 & 0.0 & 0.21 \\
\hline & $\mathrm{P}, \mathrm{L}, \mathrm{H}$ & 75.9 & 0.2 & 0.18 \\
\hline & $\mathrm{P}, \mathrm{L}, \mathrm{P} \times \mathrm{L}, \mathrm{H}$ & 76.5 & 0.8 & 0.14 \\
\hline & $\mathrm{P}, \mathrm{Cx}, \mathrm{H}$ & 77.5 & 1.8 & 0.08 \\
\hline \multirow[t]{6}{*}{ Stem height } & $\mathrm{P}, \mathrm{Cx}, \mathrm{L}, \mathrm{P} \times \mathrm{Cx}, \mathrm{P} \times \mathrm{L}$ & -38.0 & 0.0 & 0.11 \\
\hline & $\mathrm{Cx}, \mathrm{L}, \mathrm{H}$ & -37.7 & 0.3 & 0.10 \\
\hline & $\mathrm{P}, \mathrm{Cx}, \mathrm{L}, \mathrm{P} \times \mathrm{Cx}$ & -37.4 & 0.7 & 0.08 \\
\hline & $\mathrm{L}, \mathrm{H}$ & -36.7 & 1.4 & 0.06 \\
\hline & $\mathrm{P}, \mathrm{Cx}, \mathrm{P} \times \mathrm{Cx}$ & -36.3 & 1.7 & 0.05 \\
\hline & $\mathrm{Cx}, \mathrm{H}$ & -36.2 & 1.9 & 0.05 \\
\hline \multirow[t]{3}{*}{ Stem number } & $\mathrm{Cx}, \mathrm{L}, \mathrm{L} \times \mathrm{L}, \mathrm{H}$ & 290.3 & 0.0 & 0.27 \\
\hline & $\mathrm{P}, \mathrm{Cx}, \mathrm{L}, \mathrm{P} \times \mathrm{Cx}, \mathrm{L} \times \mathrm{L}, \mathrm{H}$ & 290.7 & 0.5 & 0.21 \\
\hline & $\mathrm{P}, \mathrm{Cx}, \mathrm{L}, \mathrm{P} \times \mathrm{Cx}, \mathrm{P} \times \mathrm{L}, \mathrm{L} \times \mathrm{L}, \mathrm{H}$ & 291.9 & 1.6 & 0.12 \\
\hline \multirow[t]{5}{*}{$\%$ Water content } & $\mathrm{P}, \mathrm{Cx}, \mathrm{L}, \mathrm{P} \times \mathrm{Cx}, \mathrm{P} \times \mathrm{L}, \mathrm{Cx} \times \mathrm{L}$ & -321.4 & 0.0 & 0.18 \\
\hline & $\mathrm{P}, \mathrm{Cx}, \mathrm{L}, \mathrm{P} \times \mathrm{L}, \mathrm{Cx} \times \mathrm{L}, \mathrm{Cx} \times \mathrm{Cx}$ & -321.2 & 0.2 & 0.16 \\
\hline & $\mathrm{P}, \mathrm{Cx}, \mathrm{L}, \mathrm{P} \times \mathrm{L}, \mathrm{Cx} \times \mathrm{L}$ & -320.4 & 1.0 & 0.11 \\
\hline & $\mathrm{P}, \mathrm{Cx}, \mathrm{L}, \mathrm{P} \times \mathrm{L}, \mathrm{Cx} \times \mathrm{Cx}$ & -319.7 & 1.6 & 0.08 \\
\hline & $\mathrm{P}, \mathrm{Cx}, \mathrm{L}, \mathrm{P} \times \mathrm{L}, \mathrm{Cx} \times \mathrm{L}, \mathrm{Cx} \times \mathrm{Cx}, \mathrm{H}$ & -319.7 & 1.6 & 0.08 \\
\hline Leaf toughness & $\mathrm{Cx}, \mathrm{H}$ & 330.2 & 0.0 & 0.27 \\
\hline Aphids per stem & $\mathrm{P}, \mathrm{Cx}, \mathrm{L}, \mathrm{P} \times \mathrm{Cx}, \mathrm{P} \times \mathrm{L}, \mathrm{Cx} \times \mathrm{Cx}$ & 5378.0 & 0.0 & 0.60 \\
\hline $\begin{array}{l}\text { Palatability to aphids } \\
\text { (colony mass at } 10 \text { days) }\end{array}$ & $\mathrm{P}, \mathrm{Cx}, \mathrm{L}, \mathrm{P} \times \mathrm{L}, \mathrm{Cx} \times \mathrm{Cx}, \mathrm{L} \times \mathrm{L}, \mathrm{H}$ & 1721.9 & 0.0 & 0.42 \\
\hline
\end{tabular}

Candidate models with a $\Delta_{i}$ value $\left(=\mathrm{AICc}_{i}-\mathrm{AICc}_{\text {min }}\right)$ of $\leq 2$ and the $\mathrm{AICc}$ weights $\left(w_{i}\right)$ are reported

$P$, ploidy ( $4 x$ or $8 x$ ); Cx, monoploid genome size; L, latitude of origin; $\mathrm{H}$, longitude of origin

10 days but still do not compromise colony growth because of intraspecific competition or leaf deterioration (Bhattarai et al. in review). Aphids per colony were counted, dried at $40{ }^{\circ} \mathrm{C}$ and weighed. We used colony mass at 10 days as an index of palatability.
Statistical analysis

We used generalized linear models to test whether the expression of $P$. australis growth, nutritional, defense and palatability to herbivore traits were influenced by 
ploidy, monoploid genome size and the latitude and longitude of origin of the populations. Only the two most common ploidy levels of $P$. australis were considered in this study, $4 x(\mathrm{n}=126$ source populations) and $8 x(\mathrm{n}=40)$. Because holoploid genome size (C-value) is closely correlated with ploidy level, we used monoploid genome size (Cx-value) as an explanatory variable. Ploidy was treated as a fixed effect in the model while Cx-value, latitude and longitude of origin were treated as covariates. Latitude of origin was included because the expression of plant traits, including those related to interactions with herbivores, often covary with latitude (e.g. Schemske et al. 2009) and this is particularly true for P. australis (Cronin et al. 2015). Longitude is closely correlated with previously described $P$. australis phylogeographic groups (see Lambertini et al. 2006). We also included a quadratic term for each covariate (e.g., latitude $^{2}$ ) to assess nonlinearity in the relationship between a trait and the covariate. We were particularly interested in testing for a ploidy $\times \mathrm{Cx}$-value (or ploidy $\times \mathrm{Cx}$-value ${ }^{2}$ ) interaction that would indicate that the relationship between a trait and monoploid genome size differs fundamentally between ploidy levels. Finally, all first-order interactions among predictor variables were considered. Data were analyzed using SAS 9.3 Proc Glimmix with normally distributed errors and an identity link function (SAS Institute Inc., Cary, North Carolina).

Analysis of ambient aphid abundance per stem required a slightly different analytical approach. Aphid counts per stem was Poisson distributed. Therefore, for this plant metric, we used a generalized linear model with Laplace estimation method, Poisson distribution of errors and a log link function (SAS Proc Glimmix).

To help normalize data distributions and homogenize variances between ploidy levels, total phenolics, stem heights, number of stems per pot, and aphid mass were $\ln$ transformed. Quantile-quantile plots and studentized residuals were used to identify potential outliers in the distribution of trait estimates. However, in no case did the removal of these data points qualitatively change the conclusions of the model.

For each dependent variable, we used Akaike's Information Criteria corrected for finite sample size (AICc) to select the most informative model (Burnham and Anderson 2010). We began by assessing whether quadratic terms for the three covariates $(\mathrm{Cx}-$ value, latitude of origin, longitude of origin) should be included in the candidate models for each trait. The AICc score for the base model with the main predictor variables (ploidy, Cx-value, ploidy*Cx-value) and covariate in question was compared with the AICc score for the base model plus the quadratic term for the covariate in question. If the latter model did not reduce the AICc score by $\geq 2$ relative to the base model, the quadratic term was excluded from the list of terms used for constructing candidate models (see Burnham and Anderson 2010).

Candidate models were constructed using all possible combinations of predictor variables. Restrictions to the possible combinations of variables included the requirement that interaction terms could only be present in the model if their main effects were also present in the model. Candidate models were ranked by AICc from lowest to highest value and AICs with a $\Delta_{i}$ value ( $=\mathrm{AICc}_{i}-\mathrm{AICc}_{\text {min }}$ ) of $\leq 2$ were deemed to have substantial support (Burnham and Anderson 2010). We also report the AICc weights $\left(w_{i}\right)$ which indicate the weight of evidence (as a proportion) in favor of model $i$ being the best model given the set of candidate models. As the Proc Glimmix procedure does not report goodness-of-fit for the models, we emphasize effect sizes of the factors in the model (i.e., proportional differences in least-squares means or slopes in relationships).

In order to visualize the relationship between a response variable (i.e., any of the plant traits) and a particular predictor variable (e.g., monoploid genome size), we used the following procedure. We repeated the generalized linear model analysis for the AICcbest model, with the exclusion of the predictor variable in question, and then obtained the residuals. A least-squares regression analysis or plot of the residuals against the predictor variable would reveal the effect of the predictor variable on the plant trait that is independent of the other model factors on that trait. For convenience, the $R^{2}$ and $P$ values from the regression are provided for each case as a means to gauge the model fit.

To determine whether there were any significant relationships between climate and the latitudes and longitudes of origin of the $P$. australis populations included in our study, we also conducted a correlation analysis using the data base (http://www.worldclim. org/bioclim) at 30 Arc-seconds resolution for the following variables: annual mean temperature, 
isothermality (mean diurnal range/temperature annual range), temperature seasonality (standard deviation of the temperature $\times 100$ ), maximum temperature warmest month, minimum temperature coldest month, temperature annual range, annual precipitation, seasonal precipitation, precipitation wettest quarter and precipitation driest quarter, where a quarter $=3$ months. Climate values were derived according to the methods of Hijmans et al. (2005).

\section{Results}

The monoploid genome size for $4 x P$. australis plants included in the experiment was $0.500 \pm 0.002 \mathrm{pg}$ (mean $\pm \mathrm{SE} ; n=126$ ) and ranged from $0.470 \mathrm{pg}$ to $0.573 \mathrm{pg}$. For $8 x$ plants, Cx-value was $0.501 \pm$ $0.002 \mathrm{pg}(n=40)$ and ranged from $0.485 \mathrm{pg}$ to $0.521 \mathrm{pg}$. The difference in Cx-values between tetraand octoploids was not significant $\left(\mathrm{t}_{164}=0.25\right.$, $P=0.98$ ) suggesting that no genome downsizing occurred in the octoploids that we sampled.

For the $10 P$. australis traits, the AICc best models are reported in Table 1 . In general, the most likely models explaining variation in trait expression included $\mathrm{Cx}$-value and latitude. Monoploid genome size was present in at least one of the candidate models with substantial support $(\Delta \mathrm{AICc} \leq 2)$ for all 10 traits. In fact, it was in the model with the highest likelihood (i.e., lowest AICc value) in 9 of 10 cases (the exception being total phenolics; Table 1). Among all supported models for the 10 traits $(n=35), \mathrm{Cx}$-value was a factor in $86 \%$ of them. Latitude was in the AICc-best model for 8 of 10 traits and was a factor in $86 \%$ of the models (Table 1). In descending order of importance, the percentage of models with longitude of origin, ploidy, ploidy $\times$ latitude of origin interaction, and ploidy $\times \mathrm{Cx}$-value interaction was $69 \%$ (9 of 10 traits), $60 \%$ (9 of 10 traits), $29 \%$ (6 of 10 traits), and $23 \%$ (5 of 10 traits), respectively (Table 1 ).

Although genome size was consistently included as a predictor variable of plant traits, the proportion of plant variation that was explained by $\mathrm{Cx}$-value was generally low. Table 2 shows the least-squares regression model for the relationship between $\mathrm{Cx}$-value and each plant trait after factoring out the effects of all other predictor variables from the AICc-best model. The coefficient of determination $\left(R^{2}\right)$ was $\leq 0.10$ in all cases and averaged $0.045 \pm 0.01$. One trait that was significantly related to $\mathrm{Cx}$-value was leaf toughnessplants with larger monoploid genomes tended to have tougher leaves (Fig. 1).

For stem height, leaf water content, and ambient aphid abundance, the AICc-best model suggested that the relationship between monoploid genome size and each of these traits differed between tetra- and octoploids (i.e., a ploidy $\times \mathrm{Cx}$-value interaction; Table 1). Stem height increased significantly with increasing Cx-value for tetraploids $\left(R^{2}=0.067\right.$, $P=0.004)$ but decreased with increasing $\mathrm{Cx}$-value for octoploids $\left(R^{2}=0.054, P=0.160\right)$ (Table 2; Fig. 2a). Leaf water content (Table 2; Fig. 2b) was significant for increasing $\mathrm{Cx}$-values in tetraploids but not octoploids. Finally, ambient aphid number per stem decreased significantly with $\mathrm{Cx}$-value for octoploids whereas model selection favored a non-significant quadratic relationship between aphid number and $\mathrm{Cx}$-value for the tetraploids (Table 2; Fig. 2c).

Latitude of origin was generally a better predictor of $P$. australis traits than genome size. Mean $R^{2}$ was $0.12 \pm 0.03$ for the 8 traits in which latitude of origin was in the AICc-best model (see Tables 1,2); almost three times higher than the mean $R^{2}$ for $\mathrm{Cx}$-value (see above). Regardless of ploidy level, $\%$ nitrogen decreased linearly with latitude of origin $\left(R^{2}=0.19\right.$, $P<0.001)$ and the $\mathrm{C}: \mathrm{N}$ ratio increased linearly with latitude of origin $\left(R^{2}=0.20, P<0.001\right)$. Interestingly, \% carbon and stem number per pot peaked at intermediate latitudes of origin (the AICc-best model included a quadratic function; Table 2; Fig. 3).

For four traits, stem height, leaf water content, ambient aphid abundance and aphid palatability (colony mass at 10 days), the relationship between latitude of origin and trait expression differed between tetraploids and octoploids (Table 2). For example, stem number increased $\left(R^{2}=0.11\right.$, $P=0.041)$ and leaf water content decreased $\left(R^{2}=0.32, P<0.001\right)$ with increasing latitude of origin for $8 x$ plants (Fig. 4a) but no relationship was observed for $4 x$ plants (Fig. 4b). A quadratic function best described the relationship between palatability to aphids and latitude of origin but $4 x$ plants exhibited a trough while $8 x$ plants exhibited a peak at intermediate latitudes of origin (Fig. 4c). The relationship between latitude of origin and ambient aphid abundance per stem was not statistically significant regardless of the ploidy level (Table 2). 
Table 2 Effect of the monoploid genome size (Cx-value) and latitude of origin on each Phragmites australis trait studied

\begin{tabular}{|c|c|c|c|c|}
\hline Factor & Trait & Model & $\mathrm{R}^{2}$ & $P$ \\
\hline \multirow[t]{15}{*}{ Monoploid genome size } & $\% \mathrm{C}$ & $-0.43(\mathrm{Cx})+0.23$ & 0.001 & 0.884 \\
\hline & $\% \mathrm{~N}$ & $-1.71(\mathrm{Cx})+0.85$ & 0.098 & 0.263 \\
\hline & $\mathrm{CN}$ ratio & $7.22(\mathrm{Cx})-3.59$ & 0.005 & 0.395 \\
\hline & In Stem height & & & \\
\hline & $4 x$ & $2.51(\mathrm{Cx})-1.26$ & 0.067 & 0.004 \\
\hline & $8 x$ & $-5.08(\mathrm{Cx})+2.54$ & 0.054 & 0.160 \\
\hline & ln Stem number & $-3.68(\mathrm{Cx})+1.86$ & 0.015 & 0.116 \\
\hline & $\%$ water & & & \\
\hline & $4 x$ & $0.84(\mathrm{Cx})-0.42$ & 0.067 & 0.009 \\
\hline & $8 x$ & $-1.18(\mathrm{Cx})+0.59$ & 0.063 & 0.187 \\
\hline & Leaf toughness & $5.87(\mathrm{Cx})-2.95$ & 0.030 & 0.029 \\
\hline & Aphid number & & & \\
\hline & $4 x$ & $167.44(\mathrm{Cx})-163.46\left(\mathrm{Cx}^{2}\right)-42.79$ & 0.006 & 0.699 \\
\hline & $8 x$ & $-24.59(\mathrm{Cx})+12.00$ & 0.107 & 0.048 \\
\hline & In Aphid colony mass & $-627.0(\mathrm{Cx})+614.7\left(\mathrm{Cx}^{2}\right)+159.6$ & 0.035 & 0.057 \\
\hline \multirow[t]{15}{*}{ Latitude of origin } & $\% \mathrm{C}$ & $0.11(\mathrm{~L})-0.001\left(\mathrm{~L}^{2}\right)-2.62$ & 0.061 & 0.018 \\
\hline & $\% \mathrm{~N}$ & $-0.02(\mathrm{~L})+0.80$ & 0.193 & $<0.001$ \\
\hline & $\mathrm{CN}$ ratio & $0.11(\mathrm{~L})-4.68$ & 0.203 & $<0.001$ \\
\hline & In Stem height & & & \\
\hline & $4 x$ & $0.002(\mathrm{~L})-0.085$ & 0.007 & 0.362 \\
\hline & $8 x$ & $0.011(\mathrm{~L})-0.424$ & 0.111 & 0.041 \\
\hline & $\begin{array}{l}\text { In Stem number } \\
\% \text { water }\end{array}$ & $0.190(\mathrm{~L})-0.002\left(\mathrm{~L}^{2}\right)-4.72$ & 0.293 & $<0.001$ \\
\hline & $4 x$ & $-0.0004(\mathrm{~L})+0.022$ & 0.005 & 0.492 \\
\hline & $8 x$ & $-0.005(\mathrm{~L})+0.194$ & 0.324 & 0.001 \\
\hline & Aphid number & & & \\
\hline & $4 x$ & $0.017(\mathrm{~L})-0.949$ & 0.026 & 0.082 \\
\hline & $8 x$ & $-0.004(\mathrm{~L})-0.220$ & 0.001 & 0.817 \\
\hline & In Aphid colony mass & & & \\
\hline & $4 x$ & $-0.550(\mathrm{~L})+0.006\left(\mathrm{~L}^{2}\right)+12.05$ & 0.064 & 0.019 \\
\hline & $8 x$ & $0.504(\mathrm{~L})-0.005\left(\mathrm{~L}^{2}\right)-12.08$ & 0.173 & $\mathbf{0 . 0 3 0}$ \\
\hline
\end{tabular}

If the AICc-best model contained a ploidy $\times \mathrm{Cx}$-value interaction, separate models were reported for each ploidy level. $P$ values in bold are significant $(P \leq 0.05)$. Values for each trait were obtained as the residuals from separate generalized linear model analyses that included all variables from the AICc-best model except the trait in question. Least-squares regressions were performed on the residuals to obtain the model and associated statistics

Tests of the relationship between Cx-value and plant-trait value were performed using residuals from the AICc-best model, minus $\mathrm{Cx}$-value and all interactions involving $\mathrm{Cx}$-value. The same approach was used for assessing the relationship between latitude of origin and each plant trait

In addition to ploidy-level effects on how trait expression varies with latitude of origin, ploidy per se was a modestly important predictor for one half of the plant traits considered in this study (Table 3). The most pronounced differences were that tetraploids had
$30 \%$ higher total phenolics, $14 \%$ fewer stems per pot, and $7 \%$ fewer aphids per stem than octoploids. There were other significant differences between ploidy levels, but those differences were associated with very small effect sizes-tetraploids had $3 \%$ 


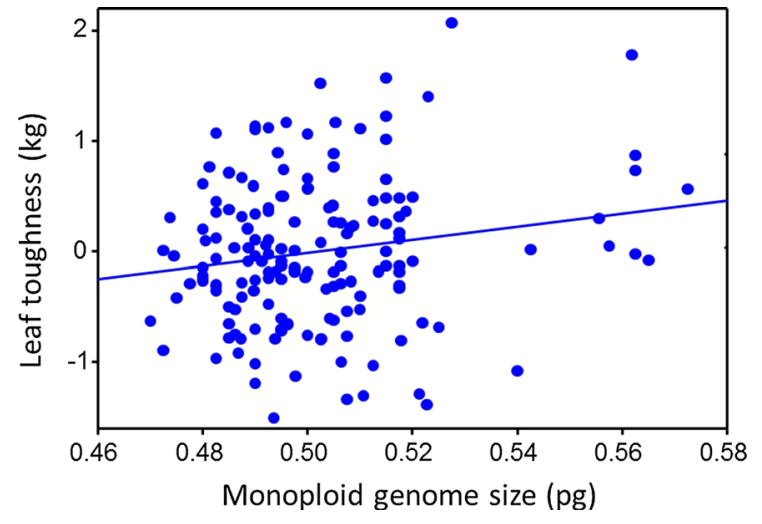

Fig. 1 The relationship between monoploid genome size (CXvalue) and $P$. australis leaf toughness $(\mathrm{kg})$. Leaf toughness values were obtained as the residuals from a generalized linear model analysis that included all variables from the AICc-best model, excluding monoploid genome size. Line is fit by leastsquares regression

taller stems and $2 \%$ less $\%$ water content than octoploids. All other traits were indistinguishable between ploidy levels (Table 3).

As indicated by the frequent occurrence of longitude of origin in the AICc-best models (see Table 1), there are differences among continents/phylogeographic groups. Interestingly, there were no interactions between longitude of origin and ploidy number or genome size. As this study is about karyological diversity and its effects on plant trait expression, no further discussion of longitude of origin is warranted.

Finally, using the variables listed above from the Bioclim database (see "Statistical analysis" section), we found a strong negative relationship $(\mathrm{r}=-0.795)$ between latitude of origin and annual mean temperature and moderately strong relationships between latitude of origin and minimum temperature in the coldest month $(\mathrm{r}=-0.595)$ and isothermality $(\mathrm{r}=-0.508)$. The correlation coefficient was weak $(r \leq 3)$ for all other variables except temperature seasonality, which was also weak at 0.306. All correlation coefficients relating longitude of origin to the 10 variables were weak $(r=<3)$ except precipitation, which showed a moderate negative relationship with longitude of origin $(r=-0.435)$ and annual precipitation, which showed a weak negative linear relationship $(\mathrm{r}=-0.361)$.
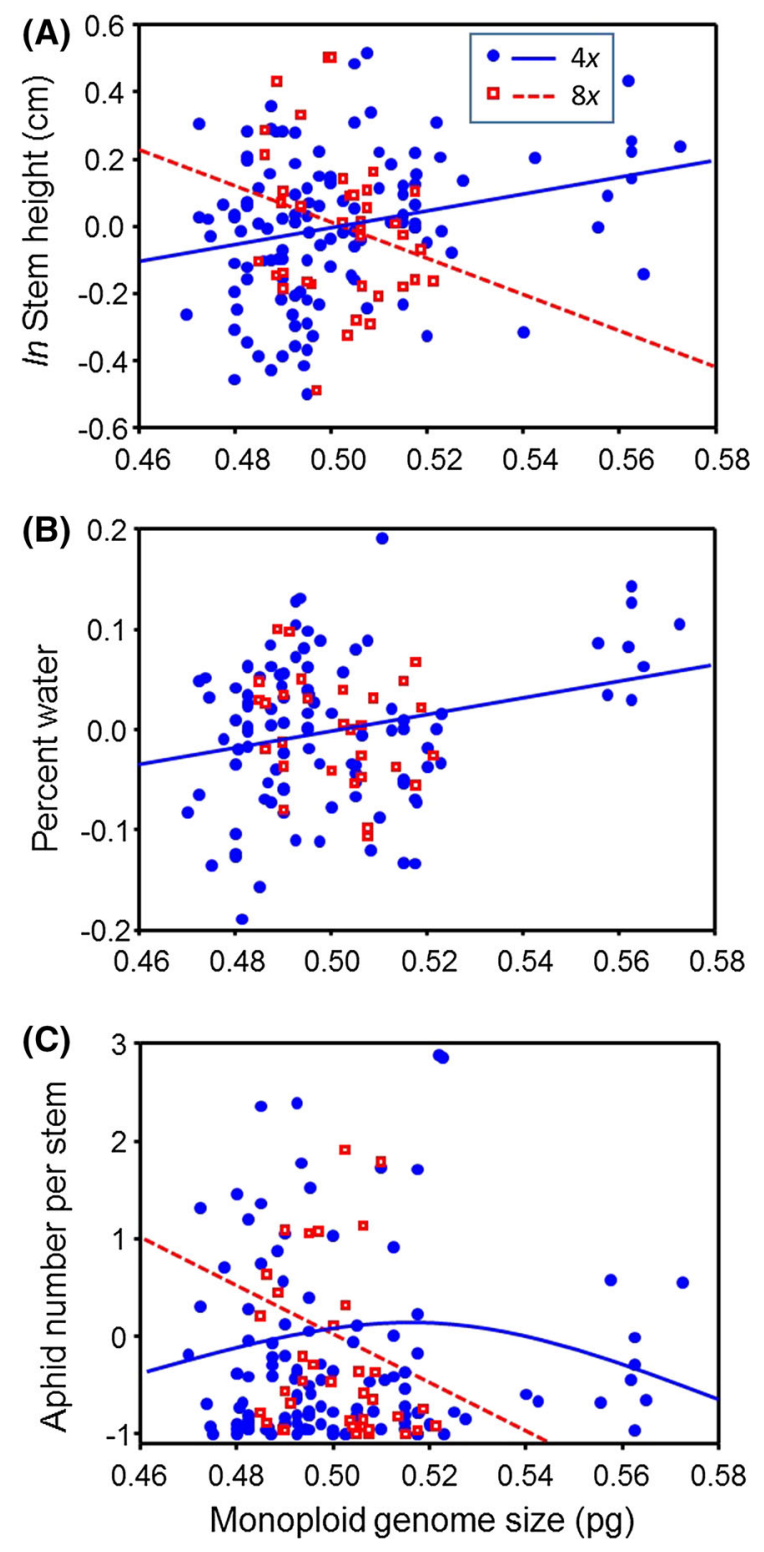

Fig. 2 The relationship between monoploid genome size $(\mathrm{Cx}-$ value) and $P$. australis. a ln stem height $(\mathrm{cm}),(\mathbf{b})$ percent water content, and $\mathbf{c}$ ambient aphid abundance per stem. Values for stem height, percent water and aphid abundance were obtained as the residuals from separate generalized linear model analyses that included all variables from the AICc-best model, excluding monoploid genome size. Because the AICc-best model (Table 1) included a ploidy*CX-value interaction, separate least-squares regression lines were fit to tetraploids and octoploids (see Table 2). Quadratic regression was used for tetraploids in (c). Note: only a single, pooled regression lines is provided in (b) because separate lines almost completely overlapped 


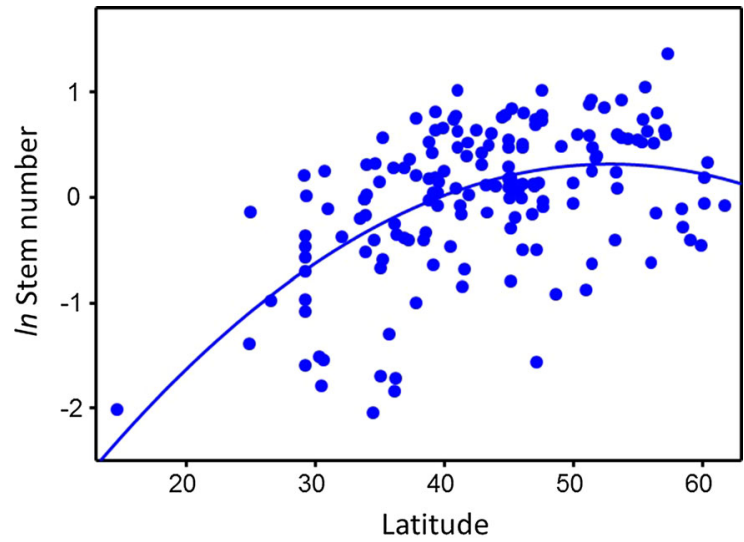

Fig. 3 The relationship between latitude of origin and number of $P$. australis stems per pot. Number of stems are the residuals from a generalized linear model analysis that included all variables from the AICc-best model, excluding latitude of origin. Line is fit by least-squares regression, band represents the $95 \%$ confidence limits and dashed lines present the $95 \%$ prediction limits

\section{Discussion}

Recent studies indicated a relationship between genome size and plant traits associated with invasiveness such as growth rate and phenology (e.g. Kubešová et al. 2010), while others showed differences between plant defense traits across ploidy levels (e.g. te Beest et al. 2011); however, the effects of genome size and ploidy level have rarely been addressed simultaneously (Pandit et al. 2014). In our common garden study we examined 126 populations of tetraploid $P$. australis spanning from $14.6^{\circ} \mathrm{N}$ to $61.8^{\circ} \mathrm{N}$ and 40 octoploid populations spanning from $39.5^{\circ} \mathrm{S}$ to $51.2^{\circ} \mathrm{N}$. We have documented significant intraspecific variation in genome size across globally distributed populations of $P$. australis. Furthermore, we examined the roles monoploid genome size, ploidy and latitude of origin (and their interactions) play in trait expression in a common garden setting that allowed us to explore the relative contributions of those factors on particular plant traits.

We found that both monoploid genome size and latitude of origin contributed to variation in nine out of the 10 traits that we studied for P. australis, with latitude of origin being generally a better predictor of trait values. Moreover, we found that ploidy level and its interaction with monoploid genome size and latitude of origin also contributed to trait variation.
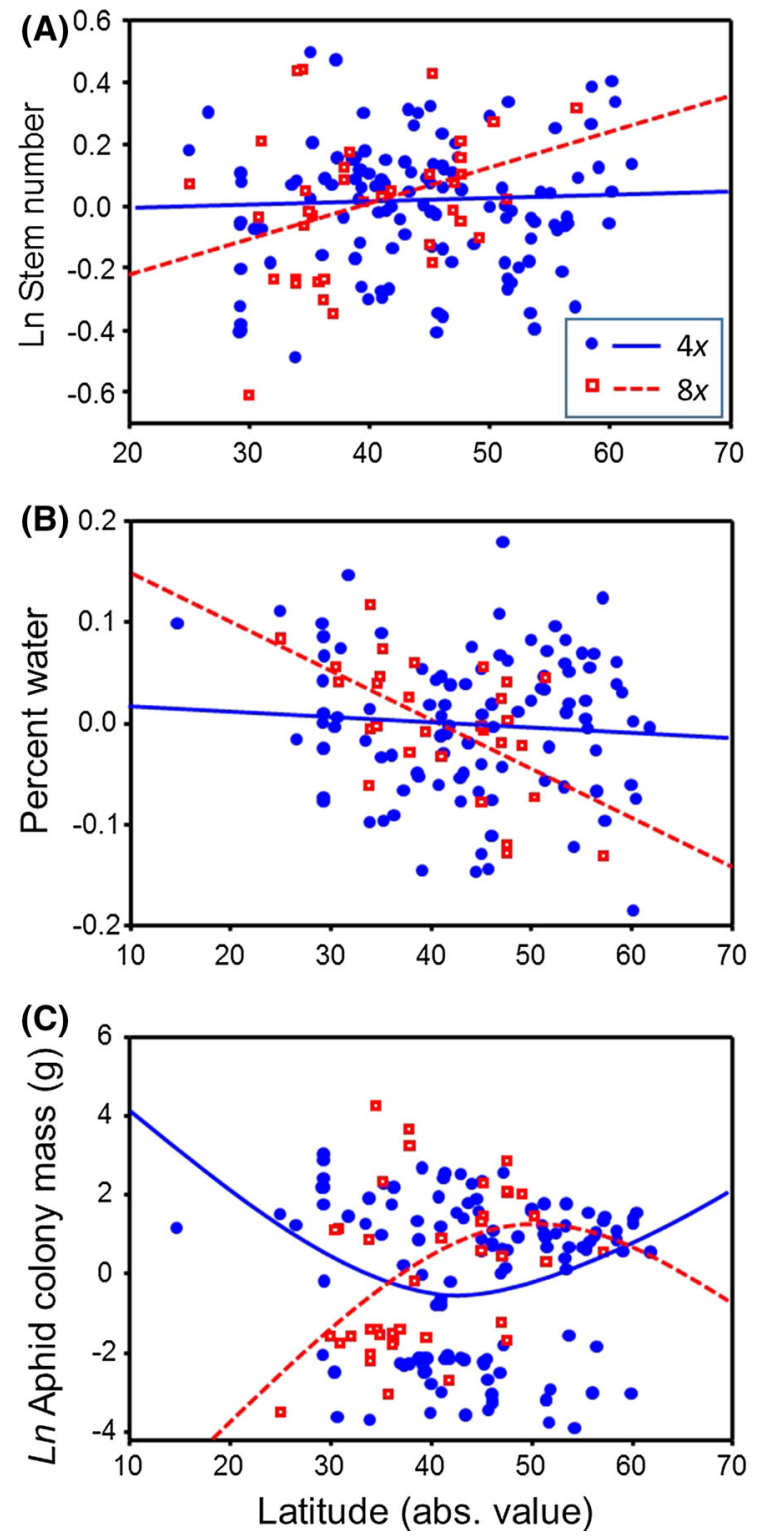

Fig. 4 The relationship between latitude of origin and $P$. australis. a stem number, b percent water content, and c palatability to aphids (colony mass at 10 days). As with the previous figures, values for each variable are the residuals from the generalized linear model analyses from the AICc-best model excluding latitude of origin

This suggests that while genome size and ploidy are each important factors that help determine plant traits, each is only a contributing factor that interacts with the other, as well as the environment, and reinforces the idea that no single trait can account for the invasion success of a species (Thébault et al. 2011). There was a 
Table 3 Least-squares mean \pm SE for $4 x$ and $8 x$ Phragmites australis

The model used to compute the least-squares means was the AICc-best model that included ploidy (see Table 1). If ploidy was not in any of the candidate models, then it was added to the model with the lowest AICc value

\begin{tabular}{lcrrr}
\hline Trait & Tetraploid $(4 x)$ & Octoploid $(8 x)$ & \multicolumn{1}{c}{ F } & \multicolumn{1}{c}{$P$} \\
\hline \% C & $46.71 \pm 0.08$ & $46.50 \pm 0.19$ & 3.66 & 0.058 \\
\% N & $3.01 \pm 0.043$ & $2.91 \pm 0.08$ & 0.86 & 0.350 \\
CN ratio & $15.69 \pm 0.21$ & $16.21 \pm 0.47$ & 0.82 & 0.368 \\
Total phenolics & $1902.1 \pm 1.03$ & $1462.9 \pm 1.07$ & 10.22 & $\mathbf{0 . 0 0 2}$ \\
Stem height & $117.33 \pm 1.02$ & $113.72 \pm 1.04$ & 4.13 & $\mathbf{0 . 0 4 4}$ \\
Stem number & $44.53 \pm 1.06$ & $52.02 \pm 1.14$ & 4.07 & $\mathbf{0 . 0 4 5}$ \\
\% water & $0.49 \pm 0.01$ & $0.50 \pm 0.01$ & 4.92 & $\mathbf{0 . 0 2 8}$ \\
Leaf toughness & $2.16 \pm 0.07$ & $2.14 \pm 0.14$ & 0.01 & 0.910 \\
Aphid number & $18.76 \pm 1.02$ & $20.01 \pm 1.06$ & 67.58 & $<\mathbf{0 . 0 0 1}$ \\
Aphid colony mass & $0.0022 \pm 0.001$ & $0.0004 \pm 0.002$ & 0.78 & 0.378 \\
\hline
\end{tabular}

significant positive relationship between monoploid genome size and leaf toughness (Fig. 1), a plant defense trait, suggesting that tougher leaves are associated with larger genomes, at least in P. australis. In a previous field study, we found that for European populations of $P$. australis, herbivory by leaf chewers and stem gallers was negatively correlated with leaf toughness; suggesting leaf toughness is an herbivoredefense trait (Cronin et al. 2015). While small genome size is associated with faster growth (Küster et al. 2008; Fridley and Craddock 2015), larger monoploid genome size in $P$. australis resulted in better-defended leaves potentially suggesting a trade-off between defense and growth rate.

We also found that for four traits, tetraploids and octoploids had different relationships with the monoploid genome size. While for tetraploids stem height and leaf water content showed a positive relationship with monoploid genome size, octoploids had a negative relationship with monoploid genome size for stem height and no relationship for leaf water content. As genome size within octoploids increased, the number of aphids colonizing leaves decreased whereas for tetraploids there was a quadratic, though non-significant, relationship. In general, we found that tetraploids were taller, chemically better defended (as suggested by the content of total phenolics), had a greater number of stems, higher leaf water content, and supported more aphids (likely due to higher leaf water content) than octoploids. However, these differences need to be interpreted with caution since the variation in genome size in tetraploids $(n=126)$ was much greater than in octoploids $(\mathrm{n}=40)$. Earlier work by Clevering et al. (2001), Hansen et al. (2007) and Achenbach et al. (2012) reported variability in the significance of plant size and physiological responses between octoploids and tetraploids depending on origin making it difficult to conclusively determine the relationship between ploidy level and $P$. australis stature. In addition, while it was more or less continuous in the latter, there was some gap in tetraploids (note that small- and largegenome tetraploids could be distinguished as distinct groups, Fig. 2). Therefore, at least some relationships may be affected by a few tetraploids with large genomes. Nevertheless, our results provide robust evidence that a wide spectrum of traits with a range of functional roles are modified in their expression by the interaction with genome size; we are not aware of any former study pointing to this phenomenon.

Latitude is often used as a proxy to investigate how species undergoing range expansions or introduction to novel environments will respond to global climate change (e.g., De Frenne et al. 2013; Kambo and Kotanen 2014) and it is expected that as the global climate warms, populations will expand their ranges poleward. The latitudes of origin for the populations used in our study showed a strong negative linear relationship with annual temperatures. Our results also showed that latitude of origin, rather than genome size or ploidy, was a better predictor of plant trait expression. Leaf nitrogen content declined at higher latitudes of origin for both ploidy levels while percent carbon increased. As with our results for monoploid genome size discussed above, we found different relationships between trait expression and latitude of origin depending on the ploidy level of the population, but these relationships were only significant for octoploid stem height (positive) and leaf water content (negative), and aphid abundance (quadratic) showed significant but opposite relationships by ploidy level. 
While many of the relationships between plant traits and genome size, ploidy and latitude of origin were weakly significant, it is worth noting that the populations included in this study represented $47^{\circ}$ of latitudinal span for tetraploids and $90^{\circ}$ of latitude for octoploids, and we therefore suggest that the results are biologically meaningful. As noted above, we analyzed three times as many tetraploids than octoploids in our sample set, which may have influenced the significance of our results. Investigating the effects of greater latitudinal range in octoploids versus tetraploids with a much larger data set could yield insights into the factors driving latitudinal differences between them.

Our results suggest that there are potential tradeoffs among plant traits mediated by monoploid genome size and ploidy with respect to fitness and defense and that the latitude of plant origin is a significant determinant of trait expression even after a decade or more of growing in a common garden setting. Under climate change, some genome size and ploidy variants (both within and among plant species) may more successfully cope with changing external filters (e.g., temperature, salinity, drought), owing to greater phenotypic plasticity and to fitness traits that vary with cytotype (e.g. Knight and Ackerly 2002; Bennett and Leitch 2005; Knight et al. 2005; Suda et al. 2015). As such, some cytotype and genome size variants may be favored by natural selection leading to changes in population genome size and/or ploidy structure, particularly at species range limits. Such changes could foster "bottom up" effects and further interact with climate change and distribution of natural enemies that are, and will continue to be, important drivers of range expansions and species invasions.

Acknowledgments The research was funded by NSF research grant 1049914 and 1050084 to JTC and LAM; S Rinehart was funded by an NSF REU to LAM. PP, JS and ML were supported by long-term research development project RVO 67985939 (The Czech Academy of Sciences), and project no. 14-15414S (Czech Science Foundation). Additional funding to LAM was provided by the US Fulbright Commission and the University of Rhode Island College of Environment and Life Sciences Agricultural Experiment Station Project RI00H-332, 311000-6044. PP acknowledges support by Praemium Academiae award from The Czech Academy of Sciences.

\section{Appendix}

\begin{tabular}{|c|c|c|c|c|c|c|}
\hline Name & Country & Continent & $\begin{array}{l}\text { Latitude of } \\
\text { origin }\end{array}$ & $\begin{array}{l}\text { Longitude of } \\
\text { origin }\end{array}$ & Ploidy & $\begin{array}{l}\text { Genome } \\
\text { size }(p g)\end{array}$ \\
\hline $\begin{array}{l}1458 \times(\mathrm{Pa} 8 \times \mathrm{AU}) \text { Australia N.S.W. Telowie, } \\
\text { Coorong }\end{array}$ & $\mathrm{AU}$ & $\mathrm{AU}$ & -32.05 & 138.07 & $8 \times$ & 4.05 \\
\hline $1488 \times(\mathrm{Pa} 8 \times \mathrm{AU})$ Australia N.S.W. Brewarrina & $\mathrm{AU}$ & $\mathrm{AU}$ & -29.95 & 146.87 & $8 \times$ & 3.98 \\
\hline $1498 \times(\mathrm{Pa} 8 \times \mathrm{AU})$ Australia N.S.W Bora Channel & $\mathrm{AU}$ & $\mathrm{AU}$ & -33.88 & 151.22 & $8 \times$ & 4.08 \\
\hline $\begin{array}{l}1508 \times(\mathrm{Pa} 8 \times \mathrm{AU}) \text { Australia N.S.W. Old } \\
\text { Willbriggie Road }\end{array}$ & $\mathrm{AU}$ & $\mathrm{AU}$ & -34.47 & 146.02 & $8 \times$ & 4.00 \\
\hline $\begin{array}{l}1568 \times(\mathrm{Pa} 8 \times \mathrm{AU}) \text { Australia N.S.W. Monkeygar } \\
\text { Creek }\end{array}$ & $\mathrm{AU}$ & $\mathrm{AU}$ & -30.75 & 147.73 & $8 \times$ & 4.11 \\
\hline $1578 \times(\mathrm{Pa} 8 \times \mathrm{AU})$ Australia N.S.W. Edward River & $\mathrm{AU}$ & $\mathrm{AU}$ & -35.74 & 145.27 & $8 \times$ & 3.91 \\
\hline $\begin{array}{l}1588 \times(\mathrm{Pa} 8 \times \mathrm{AU}) \text { Australia N.S.W. Victoria } \\
\text { Leneva Creek }\end{array}$ & $\mathrm{AU}$ & $\mathrm{AU}$ & -36.22 & 146.90 & $8 \times$ & 3.97 \\
\hline $\begin{array}{l}1628 \times(\mathrm{Pa} 8 \times \mathrm{AU}) \text { Australia N.S.W. Victoria } \\
\text { Bonegilla }\end{array}$ & $\mathrm{AU}$ & $\mathrm{AU}$ & -36.15 & 147.00 & $8 \times$ & 4.04 \\
\hline $\begin{array}{l}1678 \times(\mathrm{Pa} 8 \times \mathrm{AU}) \text { Australia N.S.W. Victoria Huges } \\
\text { Creek }\end{array}$ & $\mathrm{AU}$ & $\mathrm{AU}$ & -36.90 & 145.23 & $8 \times$ & 4.03 \\
\hline $\begin{array}{l}1738 \times(\mathrm{Pa} 8 \times \mathrm{AU}) \text { Australia N.S.W. Victoria } \\
\text { Tullaroop Creek }\end{array}$ & $\mathrm{AU}$ & $\mathrm{AU}$ & -37.82 & 144.97 & $8 \times$ & 4.02 \\
\hline $\begin{array}{l}1768 \times(\mathrm{Pa} 8 \times \mathrm{AU}) \text { Australia N.S.W. Victoria } \\
\text { Bethanga Creek }\end{array}$ & $\mathrm{AU}$ & $\mathrm{AU}$ & -36.12 & 147.10 & $8 \times$ & 4.07 \\
\hline $\begin{array}{l}968 \times \text { (Pa Core Group) Australia N.S.W. Botany } \\
\text { Wetlands }\end{array}$ & $\mathrm{AU}$ & $\mathrm{AU}$ & -33.97 & 151.20 & $8 \times$ & 4.00 \\
\hline
\end{tabular}




\begin{tabular}{|c|c|c|c|c|c|c|}
\hline Name & Country & Continent & $\begin{array}{l}\text { Latitude of } \\
\text { origin }\end{array}$ & $\begin{array}{l}\text { Longitude of } \\
\text { origin }\end{array}$ & Ploidy & $\begin{array}{l}\text { Genome } \\
\text { size }(p g)\end{array}$ \\
\hline $768 \times(\mathrm{Pa} 8 \times$ AU $)$ Australia A.C.T. Ginninderra Creek & $\mathrm{AU}$ & $\mathrm{AU}$ & -35.20 & 149.08 & $8 \times$ & 4.02 \\
\hline 136 M $8 \times$ Australia Cortina Lake & $\mathrm{AU}$ & $\mathrm{AU}$ & -34.93 & 138.60 & $8 \times$ & 4.05 \\
\hline $2188 \times ?$ Australia Victoria Melbourne & AU & $\mathrm{AU}$ & -37.83 & 144.90 & $8 \times$ & 4.04 \\
\hline $\begin{array}{l}1464 \times(\text { Pa Core Group) Belgium Scheldt, } \\
\text { Konkelschoor, Berlare }\end{array}$ & $\mathrm{BE}$ & EU & 51.22 & 4.42 & $4 \times$ & 1.98 \\
\hline $\begin{array}{l}67 \mathrm{~m} 4 \times ? \text { (Pa core group) Belgium Scheldt-estuarie } \\
\text { Burcht Antwerp }\end{array}$ & $\mathrm{BE}$ & EU & 51.22 & 4.42 & $4 \times$ & 1.96 \\
\hline $\begin{array}{l}131 \text { M 4×? (Pa Core Group) Canada Quebec } \\
\text { Huntingdon }\end{array}$ & CA & NA & 45.08 & -74.18 & $4 \times$ & 2.05 \\
\hline $\begin{array}{l}1514 \times(\mathrm{NJ} \text { Pa Alt. Coast) Canada Quebec Chemin de } \\
\text { la Butte }\end{array}$ & CA & NA & 45.50 & -73.58 & $4 \times$ & 2.07 \\
\hline $\begin{array}{l}152 \text { 4× (NJ Pa Alt. Coast) Canada Quebec Duvernay- } \\
\text { est, Montreal }\end{array}$ & CA & NA & 45.57 & -73.85 & $4 \times$ & 2.16 \\
\hline $1534 \times(\mathrm{NJ}$ Pa Alt. Coast) Canada Quebec Ormstown & CA & NA & 45.13 & -74.00 & $4 \times$ & 2.10 \\
\hline $\begin{array}{l}1544 \times \text { (Pa Core Group) Canada Quebec Saint de } \\
\text { Joliette }\end{array}$ & CA & NA & 46.03 & -73.43 & $4 \times$ & 1.98 \\
\hline 155 4× (Pa Core Group) Canada Quebec Ste-Martine & CA & NA & 45.23 & -73.80 & $4 \times$ & 2.00 \\
\hline $\begin{array}{l}204 \text { Canada MW Manitoba Lake Manitoba III, Inkster } \\
\text { Farm }\end{array}$ & CA & NA & 49.97 & -98.30 & $4 \times$ & 2.25 \\
\hline $\begin{array}{l}129 \text { M } 4 \times ? \text { (Pa Core Group) Canada Ontario Cootes } \\
\text { Paradise }\end{array}$ & CA & NA & 43.67 & -79.42 & $4 \times$ & 2.09 \\
\hline $1324 \times(\mathrm{Pa}$ Core group) Canada Quebec I'lslet sur Mer & CA & NA & 46.80 & -71.17 & $4 \times$ & 1.97 \\
\hline $\begin{array}{l}130 \text { M 4× (Pa MW) Canada Manitoba Lake Manitoba } \\
\text { Blind Channel }\end{array}$ & $\mathrm{CA}$ & NA & 49.97 & -98.30 & $4 \times$ & 2.25 \\
\hline 801 Switzerland Zurich Lake & $\mathrm{CH}$ & EU & 47.33 & 8.53 & $4 \times$ & 1.94 \\
\hline $122 \mathrm{M} 8 \times(\mathrm{Pa} 8 \times \mathrm{AU})$ China Mai Po, Hong Kong & $\mathrm{CN}$ & AS & 34.53 & 118.86 & $8 \times$ & 4.05 \\
\hline 680 China Living garden 21.04 .07 & $\mathrm{CN}$ & AS & 30.66 & 104.06 & $4 \times$ & 2.09 \\
\hline 123 M 4× (Pa Core Group) China Lanzhou & $\mathrm{CN}$ & NA & 36.06 & 103.79 & $4 \times$ & 2.02 \\
\hline $620 \mathrm{M} 4 \times$ (Pa core group) CZ-3 (CZR-L10) & $\mathrm{CR}$ & EU & 48.65 & 14.37 & $4 \times$ & 1.96 \\
\hline $\begin{array}{l}6714 \times ? \text { (Pa Africa Basel gr.) Cyprus Coral Beack, } \\
\text { Pafos }\end{array}$ & CY & EU & 35.04 & 32.43 & $4 \times$ & 1.95 \\
\hline $\begin{array}{l}6724 \times \text { (Pa Africa basel gr.) Cyprus Afrodites Bath, } \\
\text { Polis }\end{array}$ & CY & EU & 35.04 & 32.43 & $4 \times$ & 2.03 \\
\hline 641 M 4× ØТ 107 Germany & $\mathrm{DE}$ & EU & 51.43 & 13.62 & $4 \times$ & 1.97 \\
\hline 639 M 4× ØТ A Germany & $\mathrm{DE}$ & EU & 51.82 & 13.82 & $4 \times$ & 2.01 \\
\hline 640 M 4× ØТ 76 Germany & $\mathrm{DE}$ & EU & 51.43 & 13.62 & $4 \times$ & 1.97 \\
\hline $6654 \times ?$ Germany D-W6 & $\mathrm{DE}$ & EU & 51.00 & 9.90 & $4 \times$ & 1.96 \\
\hline 609 M 4× (Pa core Group) Vejlerne DK-4 (DK-W1) & DK & EU & 57.09 & 9.05 & $4 \times$ & 1.97 \\
\hline 49 M 4× (Pa Core Group) Denmark Norsminde Fjord & DK & EU & 56.02 & 10.27 & $4 \times$ & 1.99 \\
\hline 20 Denmark Fano & DK & EU & 55.40 & 8.45 & $4 \times$ & 1.93 \\
\hline 689 Denmark Laeso Haltermmen & DK & EU & 57.29 & 10.96 & $4 \times$ & 1.92 \\
\hline 21 Denmark Endelave Lynger & DK & SA & 55.76 & 10.24 & $4 \times$ & 1.96 \\
\hline $\begin{array}{l}68 \text { (Pa Africa Basel grade) Algeria Guebbour, south af } \\
\text { Hassi Messaoud }\end{array}$ & DZ & $\mathrm{AF}$ & 31.70 & 6.05 & $4 \times$ & 1.97 \\
\hline $1594 \times$ (Pa Core Group) Estonia Lake Peipsi & EE & EU & 59.02 & 27.73 & $4 \times$ & 1.93 \\
\hline
\end{tabular}




\begin{tabular}{|c|c|c|c|c|c|c|}
\hline Name & Country & Continent & $\begin{array}{l}\text { Latitude of } \\
\text { origin }\end{array}$ & $\begin{array}{l}\text { Longitude of } \\
\text { origin }\end{array}$ & Ploidy & $\begin{array}{l}\text { Genome } \\
\text { size (pg) }\end{array}$ \\
\hline 83 M 4×? (Pa Core Group) Estonia Lake Vortsjarv & EE & EU & 58.43 & 25.41 & $4 \times$ & 1.93 \\
\hline 72 M 4× (Pa Core Group) Spain Gallocanta N & ES & EU & 41.00 & -1.50 & $4 \times$ & 1.98 \\
\hline $3004 \times$ ? (Pa Core Group) Spain Mallorca Alcudia & ES & EU & 39.87 & 3.12 & $4 \times$ & 1.93 \\
\hline 74 M 4× (Pa Core Group) Spain I' encanyissada (ebro) & ES & EU & 40.72 & 0.58 & $4 \times$ & 2.06 \\
\hline $1604 \times$ (Pa Core Group) Finland Mariehamn, Aland & FI & EU & 60.10 & 19.95 & $4 \times$ & 1.93 \\
\hline $2174 \times$ ? (Pa Core Group) Finland Rsisionlahti, Turku & FI & EU & 60.40 & 22.10 & $4 \times$ & 1.95 \\
\hline $\begin{array}{l}534 \times \text { (Pa Africa Basel gr) Tunisia Ras Taguermes } \\
\text { Djerba (fine) }\end{array}$ & FI & EU & 33.82 & 11.03 & $4 \times$ & 1.98 \\
\hline $\begin{array}{l}70 \mathrm{M} 4 \times(\mathrm{Pa} \text { c. gr. basel } 8 \times \text { AU) France Campignol, } \\
\text { Narboone }\end{array}$ & FR & EU & 43.18 & 3.00 & $4 \times$ & 1.96 \\
\hline $6638 \times(\mathrm{Pa}$ core group) H-L3 8x & HU & EU & 47.60 & 17.03 & $8 \times$ & 3.95 \\
\hline $6644 \times(\mathrm{Pa}$ Core Group) Hungary H-L1 4x & HU & EU & 47.60 & 17.03 & $4 \times$ & 1.94 \\
\hline $58 \mathrm{M} 4 \times$ ? (Pa Core Group) Ireland Kilcock & IE & EU & 53.40 & -6.67 & $4 \times$ & 1.99 \\
\hline 164 4× (Pa Core Group) Ireland Lake Roe & IE & EU & 53.33 & -6.25 & $4 \times$ & 1.98 \\
\hline $1654 \times$ (Pa Core Group) Ireland Hazelhatch & IE & EU & 53.25 & -7.12 & $4 \times$ & 1.88 \\
\hline $1664 \times$ Ireland Lowtown & IE & EU & 53.43 & -7.95 & $4 \times$ & 1.93 \\
\hline $\begin{array}{l}90 \mathrm{~m} 4 \times(\text { Pa c. gr. Basel } 8 \times \text { AU) Israel Yerokham, } \\
\text { Negev Highland }\end{array}$ & IL & ME & 30.99 & 34.93 & $4 \times$ & 1.94 \\
\hline $\begin{array}{l}91 \text { M } 4 \times \text { (Pa Core Group) Israel Dead Sea South-West } \\
\text { Coast }\end{array}$ & $\mathrm{IL}$ & ME & 30.99 & 34.93 & $4 \times$ & 1.96 \\
\hline 8 Italy Sardinia S. Antioco (Saline) & IT & EU & 39.09 & 8.36 & $4 \times$ & 1.93 \\
\hline 12 Italy Sardinia Isola Rossa & IT & EU & 41.00 & 8.87 & $8 \times$ & 3.92 \\
\hline 10 (Short) Italy Sardinia Valledoria & IT & EU & 40.93 & 8.80 & $4 \times$ & 1.98 \\
\hline 11(Tall) Italy Sardinia Valledoria & IT & EU & 40.93 & 8.80 & $4 \times$ & 1.98 \\
\hline $\begin{array}{l}2074 \times ? \text { (Pa Core Group) Italy Albano S. Alessandro } \\
\text { Bergamo }\end{array}$ & IT & EU & 45.68 & 9.77 & $4 \times$ & 1.94 \\
\hline $754 \times(\mathrm{Pa}$ Core Group) Italy Gorgona & IT & EU & 43.44 & 9.92 & $4 \times$ & 1.93 \\
\hline $\begin{array}{l}684 \text { Italy } 4 \times ? \text { (Pa Core Group) Valle Bentivoglia } \\
\text { Malalbergo Bolonga }\end{array}$ & IT & EU & 44.47 & 11.63 & $4 \times$ & 2.06 \\
\hline $\begin{array}{l}685 \text { Italy } 4 \times ? \text { ? (Pa Core Group) Valle Le Tombe } \\
\text { Malalbergo Bologna }\end{array}$ & IT & EU & 44.72 & 11.53 & $4 \times$ & 2.06 \\
\hline 120 M 8× (Pa 8× AU) Japan Okoyama & $\mathrm{JP}$ & AS & 34.65 & 133.92 & $8 \times$ & 4.03 \\
\hline 686 Kuwait & $\mathrm{KW}$ & ME & 29.32 & 47.48 & $4 \times$ & 1.90 \\
\hline 85 M 4× Lithuania Silute & LT & EU & 55.35 & 21.48 & $4 \times$ & 1.95 \\
\hline 14 Libya Nemes 9 & LY & $\mathrm{AF}$ & 24.91 & 17.76 & $4 \times$ & 1.95 \\
\hline 15 Libya Mafu & LY & EU & 26.56 & 13.12 & $4 \times$ & 1.95 \\
\hline 602 M 4× (Pa core group) NL-3 (NL-L10) & NL & EU & 52.38 & 4.82 & $4 \times$ & 1.98 \\
\hline $\begin{array}{l}1634 \times \text { (Pa Core Group) Holland Verdroken Land Van } \\
\text { Saeftnghe }\end{array}$ & NL & EU & 51.33 & 4.15 & $4 \times$ & 1.96 \\
\hline $\begin{array}{l}142 \text { M } 8 \times(\mathrm{Pa} 8 \times \text { AU) New Zealand Tutaekuri River } \\
\text { Napier }\end{array}$ & NZ & $\mathrm{AU}$ & -39.48 & 176.92 & $8 \times$ & 4.05 \\
\hline 78 M 4× (Pa Core Group) Poland Krakow & PL & EU & 51.73 & 18.52 & $4 \times$ & 1.92 \\
\hline $624 \mathrm{M} 8 \times(\mathrm{Pa}$ core group) RO-1 (RO-01) & RO & EU & 45.17 & 29.33 & $8 \times$ & 3.91 \\
\hline $643 \mathrm{M} \mathrm{4 \times} \mathrm{(Pa} \mathrm{core} \mathrm{group)} \mathrm{RO-L4}$ & RO & EU & 45.00 & 29.22 & $4 \times$ & 2.01 \\
\hline $6528 \times$ (Pa core group) RO-L 3B $8 \times$ & RO & EU & 45.00 & 29.22 & $6 \times$ & 2.91 \\
\hline
\end{tabular}




\begin{tabular}{|c|c|c|c|c|c|c|}
\hline Name & Country & Continent & $\begin{array}{l}\text { Latitude of } \\
\text { origin }\end{array}$ & $\begin{array}{l}\text { Longitude of } \\
\text { origin }\end{array}$ & Ploidy & $\begin{array}{l}\text { Genome } \\
\text { size }(\mathrm{pg})\end{array}$ \\
\hline 661 RO9-8 8× (Pa Core Group) & RO & EU & 45.17 & 29.33 & $8 \times$ & 3.92 \\
\hline 657 L 5 B 4× (Pa Core Group) & RO & EU & 45.00 & 29.22 & $4 \times$ & 2.02 \\
\hline $6548 \times$ (Pa Core Group) RO-L6A $8 \times$ & RO & EU & 45.00 & 29.22 & $8 \times$ & 3.92 \\
\hline $6554 \times$ (Pa Core Group) RO-L6A 4× & RO & EU & 45.00 & 29.22 & $4 \times$ & 2.03 \\
\hline $6598 \times($ Pa Core Group) RO-L8-13 8× & RO & EU & 45.00 & 29.22 & $8 \times$ & 3.88 \\
\hline $6624 \times \mathrm{RO}-09-84 \times$ & RO & EU & 46.17 & 30.33 & $4 \times$ & 1.93 \\
\hline 84 M 8× (Pa Core Group) Romania L. Oborny & RO & EU & 45.70 & 25.80 & $6 \times$ & 2.97 \\
\hline 107 4× (Pa basel MW) Russia Moscow B, G (RAS) & RU & EU & 56.40 & 38.65 & $4 \times$ & 2.23 \\
\hline 687 Russia Novosibrisk & RU & EU & 55.02 & 82.88 & $4 \times$ & 1.97 \\
\hline $1694 \times$ (Pa Core Group) Russia St. Petersburg & RU & EU & 59.89 & 30.26 & $4 \times$ & 2.02 \\
\hline $\begin{array}{l}2158-10 \times ?(\mathrm{~Pa} 8 \times \text { AU) Russia Sakhalin Pokrovka } \\
\quad \text { Nayba }\end{array}$ & RU & EU & 47.55 & 143.32 & $8 \times$ & 4.06 \\
\hline $\begin{array}{l}2018 \times(\mathrm{Pa} 8 \times \text { AU) Russia Sakhaln Pugachevo } \\
\text { (makaraovsky distr) }\end{array}$ & RU & EU & 49.07 & 143.28 & $8 \times$ & 3.96 \\
\hline $\begin{array}{l}2128-10 \times(\mathrm{Pa} 8 \times \mathrm{AU}) \text { Russia Sakhaln Laguna Busse } \\
\text { (Korsakovsky Distr) }\end{array}$ & RU & EU & 47.03 & 143.30 & $8 \times$ & 4.15 \\
\hline 138 4× (Pa Core Group) Russia Nazyvaevsk, Omsk & RU & EU & 55.57 & 71.35 & $4 \times$ & 1.98 \\
\hline 216 6-8× (Pa Core Group) Russia Sakhaln Zaozemaya & RU & EU & 50.30 & 156.40 & $8 \times$ & 4.14 \\
\hline $\begin{array}{l}1788 \times(\text { Pa } 8 \times \text { AU) Russia Sakhalin Yuzhno- } \\
\text { Sakhalinski B,G }\end{array}$ & RU & EU & 46.95 & 142.74 & $8 \times$ & 4.17 \\
\hline $\begin{array}{l}2136-8 \times(\mathrm{Pa} 8 \times \mathrm{AU}) \text { Russia Sakhalin Voskhod } \\
\text { (Tymovsky Distr) }\end{array}$ & RU & EU & 51.42 & 143.08 & $8 \times$ & 4.14 \\
\hline $\begin{array}{l}2054 \times \text { (Pa Core Group) Russia Sakhalin Novikovo } \\
\text { (Korsakovsky Distr) }\end{array}$ & RU & EU & 47.03 & 143.30 & $4 \times$ & 1.89 \\
\hline $\begin{array}{l}2148-10 \times(\mathrm{Pa} 8 \times \text { AU) Russia Sakhalin River Manuy } \\
\text { (Dolynsky Distr) }\end{array}$ & RU & EU & 47.55 & 143.32 & $8 \times$ & 4.12 \\
\hline $3068 \times$ ? Russia Rostov & RU & EU & 57.18 & 39.45 & $8 \times$ & 3.89 \\
\hline $\begin{array}{l}110 \text { M } 8 \times(\mathrm{Pa} 8 \times \text { AU) Russia Sakhalin Okhotsk } \\
\text { (Dolynsky Distr) }\end{array}$ & RU & EU & 47.55 & 143.32 & $8 \times$ & 4.06 \\
\hline 615 M 4× (Pa core group) SE 4 A (S-W3) & SE & EU & 58.45 & 14.90 & $4 \times$ & 1.89 \\
\hline $14 \times$ ? Sweden Hornslandet Rogsta Halsingland & SE & EU & 61.76 & 17.21 & $4 \times$ & 1.91 \\
\hline $\begin{array}{l}79 \text { M } 4 \times \text { ? (Pa Core Group) Silvenia Zadnij kraj Lake } \\
\text { cerknisko }\end{array}$ & SI & EU & 46.06 & 14.51 & $4 \times$ & 1.92 \\
\hline $\begin{array}{l}1704 \times \text { (Pa Core Group) Slovenia Gornje jezero Lake } \\
\text { Cerknisko }\end{array}$ & SI & EU & 45.97 & 14.43 & $4 \times$ & 1.99 \\
\hline $1714 \times$ (Pa Core Group) Solvenia Pond Dress Ljubljana & SI & EU & 46.06 & 14.51 & $4 \times$ & 1.97 \\
\hline $1724 \times$ (Pa Core Group) Slovenia Veena pot Ljubljana & SI & EU & 46.06 & 14.51 & $4 \times$ & 1.96 \\
\hline 800 Slovenia Graga Pri Igu & SI & EU & 45.95 & 14.54 & & NA \\
\hline 102 M $4 \times$ Senegal Potte'd Oie Dakar & SN & $\mathrm{AF}$ & 14.67 & -17.44 & $4 \times$ & 1.90 \\
\hline 50 M 4× (Pa Core Group) Denmark Knebel Vig & $\mathrm{TN}$ & $\mathrm{AF}$ & 56.22 & 10.50 & $4 \times$ & 1.93 \\
\hline $\begin{array}{l}974 \times \text { (Pa African grade) Tunisia Ras Tagermes Djerba } \\
\text { (giant) }\end{array}$ & $\mathrm{TN}$ & $\mathrm{AF}$ & 33.82 & 11.03 & $8 \times$ & 3.92 \\
\hline $1744 \times$ (Pa Core Group) Tunisia Chenini (Gabes) & $\mathrm{TN}$ & $\mathrm{AF}$ & 33.88 & 10.12 & $4 \times$ & 1.92 \\
\hline 89 M $8 \times$ Turkey Aksehir & TR & EU & 38.36 & 31.42 & $8 \times$ & 4.07 \\
\hline $6824 \times$ GB-L8 & UK & EU & 53.70 & -1.70 & $4 \times$ & 1.92 \\
\hline 208 4× England River Severen & UK & EU & 53.70 & -1.70 & $4 \times$ & 1.92 \\
\hline $2094 \times$ (Pa Core Group) England Thamesmead & UK & EU & 51.50 & -0.12 & $4 \times$ & 1.93 \\
\hline
\end{tabular}




\begin{tabular}{|c|c|c|c|c|c|c|}
\hline Name & Country & Continent & $\begin{array}{l}\text { Latitude of } \\
\text { origin }\end{array}$ & $\begin{array}{l}\text { Longitude of } \\
\text { origin }\end{array}$ & Ploidy & $\begin{array}{l}\text { Genome } \\
\text { size }(p g)\end{array}$ \\
\hline 60 M 4× Scotland Tay estuary & UK & EU & 56.46 & -3.05 & $4 \times$ & 1.94 \\
\hline 63 M 4× England River Humber & UK & EU & 54.20 & -0.31 & $4 \times$ & 1.90 \\
\hline $\begin{array}{l}1176 \times(\mathrm{Pa} \text { Gulf Coast) United States Florida } \\
\text { SFWCA2A }\end{array}$ & US & NA & 25.79 & -80.13 & $6 \times$ & 3.16 \\
\hline $\begin{array}{l}1256-8 \times(\mathrm{Pa} \text { Gulf Coast) United States Louisiana } \\
\text { Weeks Island }\end{array}$ & US & NA & 29.81 & -91.81 & $6 \times$ & 3.16 \\
\hline $\begin{array}{l}1016 \times ? \text { (Pa Gulf Coast) United States Alabama } \\
\text { Dauphin island }\end{array}$ & US & NA & 30.26 & -88.11 & $6 \times$ & 3.09 \\
\hline $111 \mathrm{M} 4 \times(\mathrm{Pa} \mathrm{MW})$ United States Utah Green River & US & NA & 40.46 & -109.53 & $4 \times$ & 2.29 \\
\hline $\begin{array}{l}1904 \times(\text { NJ Pa Alt. Coast) United States New York, } \\
\text { Buffalo, Orchard Park }\end{array}$ & US & NA & 42.89 & -78.88 & $4 \times$ & NA \\
\hline $\begin{array}{l}1934 \times \text { (Pa Core Group) United States Virginia Upshur } \\
\text { Creek }\end{array}$ & US & NA & 39.30 & -75.18 & $4 \times$ & 2.03 \\
\hline $\begin{array}{l}116 \text { M } 4 \times \text { (NJ Pa Atl. Coast) United States Washington } \\
\text { Moses Lake }\end{array}$ & US & NA & 47.13 & -119.28 & $4 \times$ & 2.04 \\
\hline $1264 \times$ ? United States Louisiana Madisonville & US & NA & 30.38 & -90.16 & $6 \times$ & 3.09 \\
\hline 109 Santa Rosa Island Florida USA & US & NA & 30.40 & -86.23 & $6 \times$ & 3.12 \\
\hline $\begin{array}{l}694 \times ? \text { (Pa Core Group) United States Delaware } \\
\text { Burtons Island }\end{array}$ & US & NA & 38.58 & -75.26 & $4 \times$ & 2.09 \\
\hline $\begin{array}{l}864 \times \text { (Pa Core Group) United States Michigan Ives } \\
\text { Road Adrian }\end{array}$ & US & NA & 41.90 & -84.04 & $4 \times$ & 2.22 \\
\hline $54 \mathrm{M} 4 \times$ ? (Pa Core Group) Finland Husoviken Aland & US & NA & 60.10 & 19.95 & $4 \times$ & 1.95 \\
\hline $\begin{array}{l}994 \times(\text { Pa Core Group) United States North Carolina } \\
\text { Avon, Pea island }\end{array}$ & US & NA & 36.27 & -77.59 & $4 \times$ & 2.04 \\
\hline $\begin{array}{l}554 \times(\mathrm{Pa} \mathrm{MW}) \text { United States Minnesota Bluestern } \\
\text { prairie }\end{array}$ & US & NA & 46.87 & -96.77 & $4 \times$ & 2.25 \\
\hline 113 Rhode Island Galilee & US & NA & 47.13 & -119.28 & $4 \times$ & 2.04 \\
\hline 115 M 4× United States Maryland Easton Talbot & US & NA & 38.77 & -76.08 & $4 \times$ & 2.02 \\
\hline $\begin{array}{l}114 \text { M } 4 \times ? \text { (NJ Pa Atl. Coast) United States Ohio } \\
\text { Maumee Bay }\end{array}$ & US & NA & 41.56 & -83.65 & $4 \times$ & 2.06 \\
\hline 113 M 4×? Unites States Rhode Island Galilee & US & NA & 41.38 & -71.51 & $4 \times$ & 2.05 \\
\hline $2104 \times$ ? United States Virginia James Town island & US & NA & 37.21 & -76.77 & $4 \times$ & 2.02 \\
\hline $1284 \times$ ? United States Massachusetts Buzzards Bay & US & NA & 41.75 & -70.62 & $4 \times$ & 2.06 \\
\hline $614 \times$ United states Illinois La salle-Peru & US & NA & 41.33 & -89.11 & $4 \times$ & 2.00 \\
\hline $1214 \times$ (Pa Core Group) United States Florida Crayton & US & NA & 30.33 & -86.17 & $4 \times$ & 1.96 \\
\hline $\begin{array}{l}\text { OCT } 1 \text { Greeny1-214 Mississippi River Delta Louisiana } \\
\text { USA }\end{array}$ & US & NA & 29.21 & -89.22 & $4 \times$ & 1.99 \\
\hline $\begin{array}{l}\text { ROMS7 Delta-210 Mississippi River Delta Louisiana } \\
\text { USA }\end{array}$ & US & NA & 29.25 & -89.24 & $4 \times$ & 1.92 \\
\hline WHS2 EU-211 Mississippi River Delta Louisiana USA & US & NA & 29.21 & -89.21 & $4 \times$ & 2.03 \\
\hline $2024 \times$ ? United States New Mexico Bitter River & US & NA & 33.47 & -104.42 & $4 \times$ & 2.25 \\
\hline $\begin{array}{l}\text { WHS3 Land-212 Mississippi River Delta Louisiana } \\
\text { USA }\end{array}$ & US & NA & 29.21 & -89.21 & $6 \times$ & 3.17 \\
\hline $2034 \times$ United States New Jersey Stone Harbor & US & NA & 39.06 & -74.77 & $4 \times$ & 2.07 \\
\hline $\begin{array}{l}654 \times ?(\mathrm{~Pa} \mathrm{MW}) \text { United States Michigan Daytin West } \\
\text { Prairie }\end{array}$ & US & NA & 41.00 & 83.00 & $4 \times$ & 2.26 \\
\hline $\begin{array}{l}1196 \times(\mathrm{Pa} \text { Core Group) United States Louisiana } \\
\text { Cocodrie }\end{array}$ & US & NA & 29.25 & -90.66 & $4 \times$ & 1.95 \\
\hline
\end{tabular}




\begin{tabular}{|c|c|c|c|c|c|c|}
\hline Name & Country & Continent & $\begin{array}{l}\text { Latitude of } \\
\text { origin }\end{array}$ & $\begin{array}{l}\text { Longitude of } \\
\text { origin }\end{array}$ & Ploidy & $\begin{array}{l}\text { Genome } \\
\text { size (pg) }\end{array}$ \\
\hline $\begin{array}{l}714 \times ? \text { (Pa Core Group) United States New York } \\
\text { Buffaki, Great Baehre }\end{array}$ & US & NA & 42.89 & -78.88 & $4 \times$ & 2.08 \\
\hline ROM2 EU-209 Mississippi River Delta Louisiana USA & US & NA & 29.26 & -89.24 & $4 \times$ & 2.08 \\
\hline $\begin{array}{l}\text { ROM4 Delta-215 Mississippi River Delta Louisiana } \\
\text { USA }\end{array}$ & US & NA & 29.26 & -89.24 & $4 \times$ & 2.07 \\
\hline $\begin{array}{l}112 \text { M 4×? (NJ Pa Alt. Coast) United States Delaware } \\
\text { Roosevelt Inlet }\end{array}$ & US & NA & 39.94 & -74.39 & $4 \times$ & 2.17 \\
\hline $\begin{array}{l}\text { ROM16 Land-207 Mississippi River Delta Louisiana } \\
\text { USA }\end{array}$ & US & NA & 29.20 & -89.25 & $6 \times$ & 3.17 \\
\hline $\begin{array}{l}\text { SEP107 Greeny3-107 Mississippi River Delta Louisiana } \\
\text { USA }\end{array}$ & US & NA & 29.14 & -89.14 & $4 \times$ & 1.98 \\
\hline $1794 \times($ NJ Pa Atl. Coast) United States Delaware Dover & US & NA & 39.16 & -75.52 & $4 \times$ & 2.00 \\
\hline $1804 \times$ (NJ Pa Atl. Coast) United States Loms Pond & US & NA & 39.58 & -75.71 & $4 \times$ & 2.07 \\
\hline $\begin{array}{l}1814 \times(\mathrm{NJ} \text { Pa Atl. Coast) United States Delaware } \\
\text { Odessa }\end{array}$ & US & NA & 39.46 & -75.66 & $4 \times$ & 1.97 \\
\hline $1824 \times$ United States Delaware Willow Creek & US & NA & 38.78 & -75.11 & $4 \times$ & 2.07 \\
\hline $1854 \times$ United States Maryland Webster Field & US & NA & 38.79 & -77.29 & $4 \times$ & 2.05 \\
\hline $\begin{array}{l}1864 \times \text { (Pa Core Group) United States Virginia Oyster } \\
\text { Delmarva }\end{array}$ & US & NA & 37.29 & -75.92 & $4 \times$ & 1.99 \\
\hline $\begin{array}{l}1874 \times ? \text { (NJ Pa Atl. Coast) United States Virginia } \\
\text { Parramore Island }\end{array}$ & US & NA & 39.30 & -75.18 & $4 \times$ & 2.06 \\
\hline $\begin{array}{l}1894 \times(\text { NJ Pa Atl. Coast) United States Virginia } \\
\text { Mutton Hunk }\end{array}$ & US & NA & 37.78 & -75.60 & $4 \times$ & 2.00 \\
\hline $\begin{array}{l}1914 \times \text { (Atl. Coast) United States New York N. } \\
\text { Wheatfield Bear Ridge }\end{array}$ & US & NA & 43.28 & -77.28 & $4 \times$ & 2.02 \\
\hline $\begin{array}{l}1924 \times \text { (NJ Pa Atl. Coast) United States Virginia Swash } \\
\text { Bay }\end{array}$ & US & NA & 39.30 & -75.18 & $4 \times$ & 1.97 \\
\hline $\begin{array}{l}1944 \times \text { (NJ Pa Atl. Coast) United States Virginia } \\
\text { Virginia Beach }\end{array}$ & US & NA & 36.85 & -75.98 & $4 \times$ & 2.11 \\
\hline $\begin{array}{l}1974 \times(\text { NJ Pa Alt. Coast) United States New York } \\
\text { Buffalo, Depew }\end{array}$ & US & NA & 42.90 & -78.69 & $4 \times$ & 2.00 \\
\hline $\begin{array}{l}1994 \times(\text { NJ Pa Atl. Coast) United States Massachusetts } \\
\text { Bedford Boston }\end{array}$ & US & NA & 42.49 & -71.28 & $4 \times$ & 2.07 \\
\hline $\begin{array}{l}2004 \times \text { (NJ Pa Atl. Coast) United States Rhode Island } \\
\text { Silver Spring Lake }\end{array}$ & US & NA & 41.79 & -71.37 & $8 \times$ & 4.12 \\
\hline $\begin{array}{l}2064 \times(\text { NJ Pa Atl. Coast) United States Connecticut } \\
\text { Milford }\end{array}$ & US & NA & 41.22 & -73.06 & $4 \times$ & 1.99 \\
\hline $2114 \times ?(\mathrm{~Pa}$ MW) United States Minnesota Pipestone & US & NA & 44.00 & -96.32 & $4 \times$ & 2.02 \\
\hline $\begin{array}{l}2244 \times ? \text { (Pa Gulf Coast) United States Mississippi } \\
\text { Christian }\end{array}$ & US & NA & 35.22 & -88.04 & $4 \times$ & 1.97 \\
\hline 144 Rockefeller Louisiana USA & US & NA & 29.74 & -92.82 & $6 \times$ & 3.09 \\
\hline $\begin{array}{l}\text { ROMS4 Delta-208 Mississippi River Delta Louisiana } \\
\text { USA }\end{array}$ & US & NA & 29.26 & -89.24 & $4 \times$ & 2.07 \\
\hline $\begin{array}{l}1888 \times(\mathrm{NJ} \text { Pa } 8 \times \mathrm{ZA}) \text { Rep. South Africa } \\
\text { Loeriesfontein }\end{array}$ & $\mathrm{ZA}$ & $\mathrm{AF}$ & -30.97 & 19.45 & $8 \times$ & 3.95 \\
\hline $1958 \times($ NJ Pa $8 \times$ ZA) Rep. South Africa Brandvlei & $\mathrm{ZA}$ & $\mathrm{AF}$ & -30.45 & 20.48 & $8 \times$ & 3.88 \\
\hline $\begin{array}{l}105 \text { M } 8 \times \text { (Pa Core Group) Rep. South Africa } \\
\text { Keurboom Estuary }\end{array}$ & $\mathrm{ZA}$ & $\mathrm{AF}$ & -33.95 & 18.46 & $8 \times$ & 3.93 \\
\hline $3118 \times(\mathrm{NJ} P a \mathrm{P} \times \mathrm{ZA})$ Rep. South Africa Kalkgat & $\mathrm{ZA}$ & $\mathrm{AF}$ & -24.98 & 28.63 & $8 \times$ & 3.89 \\
\hline
\end{tabular}




\section{References}

Achenbach L, Lambertini C, Brix H (2012) Phenotypic traits of Phragmites australis clones are not related to ploidy level and distribution range. AoB Plants. doi:10.1093/aobpla/ pls017

Albert CH et al (2010) Intraspecific functional variability: extent, structure and sources of variation. J Ecol 98:604-613

Arvanitis L, Wiklund C, Munzbergová Z, Dahlgren JP, Ehrlén J (2010) Novel antagonistic interactions associated with plant polyploidization influence trait selection and habitat preference. Ecol Lett 13:330-337

Balao F, Herrera J, Talavera S (2011) Phenotypic consequences of polyploidy and genome size at the microevolutionary scale: a multivariate morphological approach. N Phytol 192:256-265

Bennett MD, Leitch IJ (2005) Genome size evolution in plants. In: Gregory T (ed) The evolution of the genome. Elsevier, San Diego, pp 89-162

Bhattarai GP, Meyerson LA, Anderson J, Cummings D, Allen WJ, Cronin J (2016) The biogeography of a plant invasion: genetic variation and plasticity in latitudinal clines for plant-herbivore interaction traits. Ecol Monogr (in review)

Boalt E, Arvanitis L, Lehtilä K, Ehrlén J (2010) The association among herbivory tolerance, ploidy level, and herbivory pressure in Cardamine pratensis. Evol Ecol 24:1101-1113

Burnham KP, Anderson DR (2010) Model selection and multimodel inference: a practical information-theoretic approach, 2nd edn. Springer, New York

Cardinale BJ, Duffy JE, Gonzalez A, Hooper DU, Perrings C, Venail P, Narwani A, Mace GM, Tilman D, Wardle DA, Kinzig AP, Daily GC, Loreau M, Grace JB, Larigauderie A, Srivastava D, Naeem S (2012) Biodiversity loss and its impact on humanity. Nature 486:59-67

Chambers RM, Meyerson LA, Saltonstall K (1999) Expansion of reed into tidal wetlands of North America. Aquat Bot 64:261-273

Clevering OA, Lissner J (1999) Taxonomy, chromosome numbers, clonal diversity and population dynamics of Phragmites australis. Aquat Bot 64:185-208

Clevering O, Brix H, Lukavská J (2001) Geographic variation in growth responses in Phragmites australis. Aquat Bot 69:89-108

Collins AR, Thalmann D, Müller-Schärer H (2013) Cytotypes of Centaurea stoebe found to differ in root growth using growth pouches. Weed Res 53:159-163

Crawford KM, Rudgers JA (2013) Genetic diversity within a dominant plant outweighs plant species diversity in structuring an arthropod community. Ecology 94:1025-1035

Cronin JT, Bhattarai GP, Allen WJ, Meyerson LA (2015) Biogeography of a plant invasion: plant-herbivore interactions. Ecology 96:1115-1127

De Frenne P, Graae BJ, Rodríguez-Sánchez F, Kolb A, Chabrerie O, Decocq G, De Kort H, De Schrijver A, Diekmann M, Eriksson O, Gruwez R, Hermy M, Lenoir J, Plue J, Coomes DA, Verheyen K (2013) Latitudinal gradients as natural laboratories to infer species' responses to temperature. J Ecol 101:784-795

Doležel J, Greilhuber J, Suda J (2007) Estimation of nuclear DNA content in plants using flow cytometry. Nat Prot 2:2233-2244
Fagan WF, Aumann C, Kennedy CM, Unmack PJ (2005) Rarity, fragmentation, and the scale dependence of extinction risk in desert fishes. Ecology 86:34-41

Fridley JD, Craddock A (2015) Contrasting growth phenology of native and invasive forest shrubs mediated by genome size. N Phytol 207:659-668

Greilhuber J, Doležel J, Lysák MA, Bennett MD (2005) The origin, evolution and proposed stabilization of the terms 'genome size' and 'C-value' to describe nuclear DNA contents. Ann Bot 95:255-260

Hahn PG, Dornbush ME (2012) Exotic consumers interact with exotic plants to mediate native plant survival in a Midwestern forest herb layer. Biol Invasions 14:449-460

Halverson K, Heard SB, Nason JD, Stireman JO III (2008) Differential attack on diploid, tetraploid, and hexaploid Solidago altissima L. by five insect gallmakers. Oecologia 154:755-761

Hansen D, Lambertini C, Jampeetong A, Brix H (2007) Clonespecific differences in Phragmites australis: effects of ploidy level and geographic origin. Aquat Bot 86:269-279

Hao GY et al (2013) Polyploidy enhances the occupation of heterogeneous environments through hydraulic related trade-offs in Atriplex canescens (Chenopodiaceae). N Phytol 197:970-978

Henery ML, Bowmann G, Mráz P, Trier UA, Gex-Fabry E, Schaffner U, Müller-Schärer H (2010) Evidence for a combination of pre-adapted traits in the invasive plant Centaurea stoebe. J Ecol 98:800-813

Hijmans RJ, Cameron SE, Parra JL, Jones PG, Jarvis A (2005) Very high resolution interpolated climate surfaces for global land areas. Int J Climatol 25:1965-1978

Hughes AR, Stachowicz JJ (2004) Genetic diversity enhances the resistance of a seagrass ecosystem to disturbance. Proc Natl Acad Sci USA 101:8998-9002

Hull-Sanders HM, Johnson RH, Owen HA, Meyer GA (2009) Influence of polyploidy on insect herbivores of native and invasive genotypes of Solidago gigantean (Asteraceae). Plant Signal Behav 4:893-895

Hulme P, Pyšek P, Jarošik V, Pergl J, Schaffner U, Vila M (2013) Bias and error in understanding invasions and impacts. TREE 28:212-218

Janz N, Thompson JN (2002) Plant polyploidy and host expansion in an insect herbivore. Oecologia 130:570-575

Johnson JB, Peat SM, Adams BJ (2009) Where's the ecology in molecular ecology? Oikos 118:1601-1609

Kambo D, Kotanen PM (2014) Latitudinal trends in herbivory and performance of an invasive species, common burdock (Arctium minus). Biol Invasions 16:101-112

Keane RM, Crawley MJ (2002) Exotic plant invasions and the enemy release hypothesis. Trends Ecol Evol 17:164-170

Keller BE (2000) Genetic variation among and within populations of Phragmites australis in the Charles River watershed. Aquat Bot 66:195-208

Kiviat E (2013) Ecosystem services of Phragmites in North America with emphasis on habitat functions. AoB Plants 5:plt008

Knight CA, Ackerly DD (2002) Variation in nuclear DNA content across environmental gradients: a quantile regression analysis. Ecol Lett 5:66-76

Knight CA, Molinari NA, Petrov DA (2005) The large genome constraint hypothesis: evolution, ecology and phenotype. AoB 95:177-190 
Kubešová M, Moravcová L, Suda J, Jarošík V, Pyšek P (2010) Naturalized plants have smaller genomes than their noninvading relatives: a flow cytometric analysis of the Czech alien flora. Preslia 82:81-96

Küster EC, Kühn I, Bruelheide H, Klotz S (2008) Trait interactions help explain plant invasion success in the German flora. J Ecol 96:860-868

Lambertini C, Gustafsson MHG, Frydenberg J, Lissner J, Speranza M, Brix H (2006) A phylogeographic study of the cosmopolitan genus Phragmites (Poaceae) based on AFLPs. Plant Syst Evol 258:161-182

Lambertini C, Mendelssohn IA, Gustafsson MH, Olesen B, Riis T, Sorrell BK, Brix H (2012) Tracing the origin of Gulf Coast Phragmites (Poaceae): a story of long-distance dispersal and hybridization. Am J Bot 99:538-551

Lavergne S, Muenke NJ, Molofsky J (2010) Genome size reduction can trigger rapid phenotypic evolution in invasive plants. AoB 105:109-116

Lavorel S, Díaz S, Cornelissen JHC, Garnier E, Harrison SP, McIntyre S, Pausas JG, Pérez-Harguindeguy N, Roumet C, Urcelay C (2007) Plant functional types: Are we getting any closer to the Holy Grail? In: Canadell JG, Pataki DE, Pitelka LF (eds) Terrestrial ecosystems in a changing world. Springer, NewYork, pp 149-164

Levin DA (2002) The role of chromosomal change in plant evolution. Oxford University Press, Oxford

Lozier JD, Roderick GK, Mills NJ (2009) Tracing the invasion history of mealy plum aphid, Hyalopterus pruni (Hemiptera: Aphididae), in North America: a population genetics approach. Biol Invasions 11:299-314

Meyerson LA, Lambert AM, Saltonstall K (2010) A tale of three lineages: expansion of common reed (Phragmites australis) in the U.S. southwest and Gulf Coast. Invasive Plant Sci Manage 3:515-520

Meyerson LA, Lambertini C, McCormick M, Whigham D (2012) Hybridization of common reed in North America? The answer is blowing in the wind. AoB Plants. doi:10. 1093/aobpla/pls022

Meyerson LA, Cronin JT, Pyšek P (2016) Phragmites as a model organism for plant invasions. Biol Invasions. doi:10.1007/ s10530-016-1132-3

Mitchell CE, Power AG (2003) Release of invasive plants from fungal and viral pathogens. Nature 421:625-627

Mitchell CE, Blumenthal D, Jarošík V, Puckett EE, Pyšek P (2010) Controls on pathogen species richness in plants' introduced and native ranges: roles of residence time, range size, and host traits. Ecol Lett 13:1525-1535

Münzbergová Z (2006) Ploidy level interacts with population size and habitat conditions to determine the degree of herbivory damage in plant populations. Oikos 115:443-452

Packer J, Meyerson LA, Skálová H, Haslam S, Pyšek P, Kueffer C (2016) Biological flora of British Isles. Phragmites australis. J Ecol (in review)
Pandit MK, White S, Pocock MJO (2014) The contrasting effects of genome size, chromosome number and ploidy level on plant invasiveness: a global analysis. N Phytol 203:697-703

Pyšek P, Jarošík V, Pergl J, Randall R, Chytrý M, Kühn I, Tichý L, Danihelka J, Chrtek jun J, Sádlo J (2009) The global invasion success of Central European plants is related to distribution characteristics in their native range and species traits. Divers Distrib 15:891-903

Pyšek P, Manceur AM, Alba C, McGregor KF, Pergl J, Štajerová K, Chytrý M, Danihelka J, Kartesz J, Klimešová J, Lučanová M, Moravcová L, Nishino M, Sádlo J, Suda J, Tichý L, Kühn I (2015) Naturalization of central European plants in North America: species traits, habitats, propagule pressure, residence time. Ecology 96:762-774

Reusch TBH, Hughes AR (2006) The emerging role of genetic diversity for ecosystem functioning: estuarine macrophytes as models. Estuar Coasts 29:159-164

Saltonstall K (2002) Cryptic invasion by a non-native genotype of the common reed, Phragmites australis, into North America. Proc Natl Acad Sci USA 99:2445-2449

Schemske DW, Mittelbach GG, Cornell HV, Sobel JM, Roy K (2009) Is there a latitudinal gradient in the importance of biotic interactions? Annu Rev Ecol Evol Syst 40:245-269

Sides CB, Enquist BJ, Ebersole JJ, Smith MN, Henderson AN, Sloat LL (2014) Revisiting Darwin's hypothesis: Does greater intraspecific variability increase species' ecological breadth? Am J Bot 101:56-62

Stachowicz JJ, Bruno JF, Duffy JE (2007) Understanding the effects of marine biodiversity on communities and ecosystems. AREES 38:739-766

Suda J, Meyerson LA, Pyšek P, Leitch I (2015) The hidden side of plant invasions: the role of genome size. N Phytol 205:994-1007

te Beest M, Le Roux JJ, Richardson DM, Brysting AK, Suda J, Kubešová M, Pyšek P (2011) The more the better? The role of polyploidy in facilitating plant invasions. Ann Bot 109:19-45

Tewksbury L, Casagrande R, Blossey B, Hafliger P, Schwarzlander M (2002) Potential for biological control of Phragmites australis in North America. Biol Control 23:191-212

Thébault A, Gillet F, Müller-Schärer H, Buttler A (2011) Polyploidy and invasion success: trait trade-offs in native and introduced cytotypes of two Asteraceae species. Plant Ecol 212:315-325

Thompson JN, Merg KF (2008) Evolution of polyploidy and the diversification of plant-pollinator interactions. Ecology 89:2197-2206

Waterman PG, Mole S (1994) Analysis of plant phenolic metabolites. Blackwell Scientific Publications, Oxford 